\title{
Epigenetic modifications in acute myeloid leukemia: The emerging role of circular RNAs (Review)
}

\author{
MOHAMMED AWAL ISSAH ${ }^{1,2}$, DANSEN WU ${ }^{3}$, FENG ZHANG $^{1,2}$, WEILI ZHENG ${ }^{1,2}$, YANQUAN LIU $^{1,2}$, \\ HAIYING FU ${ }^{1,2}$, HUARONG ZHOU ${ }^{1,2}$, RONG CHEN $^{1,2}$ and JIANZHEN SHEN ${ }^{1,2}$ \\ ${ }^{1}$ Fujian Institute of Hematology, Fujian Medical Center of Hematology, Clinical Research Center for Hematological \\ Malignancies of Fujian Province; ${ }^{2}$ Fujian Provincial Key Laboratory on Hematology, Fujian Medical University \\ Union Hospital; ${ }^{3}$ Medical Intensive Care Unit, Fujian Provincial Hospital, Fuzhou, Fujian 350001, P.R. China
}

Received June 23, 2021; Accepted September 13, 2021

DOI: $10.3892 /$ ijo.2021.5287

\begin{abstract}
Canonical epigenetic modifications, which include histone modification, chromatin remodeling and DNA methylation, play key roles in numerous cellular processes. Epigenetics underlies how cells that posses DNA with similar sequences develop into different cell types with different functions in an organism. Earlier epigenetic research has primarily been focused at the chromatin level. However, the number of studies on epigenetic modifications of RNA, such as $\mathrm{N}^{1}$-methyladenosine, 2'-O-ribosemethylation, inosine, 5-methylcytidine, $\mathrm{N}^{6}$-methyladenosine $\left(\mathrm{m}^{6} \mathrm{~A}\right)$ and pseudouridine, has seen an increase. Circular RNAs (circRNAs), a type of RNA species that lacks a $5^{\prime}$ cap or $3^{\prime}$ poly(A) tail, are abundantly expressed in acute myeloid leukemia (AML) and may regulate disease progression. circRNAs possess various functions, including microRNA sponging, gene transcription regulation and RNA-binding protein interaction. Furthermore, circRNAs are $\mathrm{m}^{6} \mathrm{~A}$ methylated in other types of cancer, such as colorectal and hypopharyngeal squamous cell cancers. Therefore, the critical roles of circRNA epigenetic modifications, particularly $\mathrm{m}^{6} \mathrm{~A}$, and their possible involvement in AML are discussed in the present review. Epigenetic modification of circRNAs may become a diagnostic and therapeutic target for AML in the future.
\end{abstract}

\section{Contents}

1. Introduction

2. AML and canonical epigenetics

3. RNA modification

4. $\mathrm{m}^{6} \mathrm{~A}$ modification

Correspondence to: Professor Jianzhen Shen, Fujian Institute of Hematology, Fujian Medical Center of Hematology, Clinical Research Center for Hematological Malignancies of Fujian Province, 29 Xinquan Road, Fuzhou, Fujian 350001, P.R. China

E-mail: doctorsjz@163.com

Key words: circular RNA, epigenomics, acute myeloid leukemia, $\mathrm{N}^{6}$-methyladenosine, non-coding RNA
5. Other RNA modifications

6. Epigenetic modifications of circRNAs

7. circRNAs and AML

8. circRNA epigenetic modifications and their possible roles in AML

9. Conclusion

\section{Introduction}

Acute myeloid leukemia (AML) is the most common type of adult leukemia, with a wide range of biological and clinical characteristics (1). A total of 19,520 new cases of AML were reported in the US in 2018 (2), and 14,100 cases were reported in China in 2015, according to survey data (3). Genetic and epigenetic abnormalities have been identified to play key roles in the pathogenesis of AML (4,5).

Epigenomics, which refers to the epigenetic changes that modify the expression of a genotype into a particular phenotype without any alteration of the genetic material, play key roles in mammalian growth and maturation (6). Canonical epigenetics research had previously focused on the modifications and variations of DNA in chromatin, whereas epigenetic modifications of RNA, particularly those involving non-coding RNAs, have been attracting increasing attention recently. With the advancement of RNA deep sequencing technologies and bioinformatics approaches, circular (circ)RNAs have become increasingly significant among RNA species. Distinct from linear RNAs, circRNAs have loop structures that are covalently closed and lack 5' caps and $3^{\prime}$ poly(A) tails due to back-splicing (7). Due to their stability (8), evolutionary conservatism (9) and abundance (10), circRNAs act as microRNA (miRNA/miR) sponges $(4,11)$, RNA splicing factors (12) and parental gene expression modulators (13). In addition, circRNAs have been detected to serve as biomarkers for a wide range of diseases, including gastric and hepatocellular cancers (14). Furthermore, studies have shown that circRNAs are $\mathrm{N}^{6}$-methyladenosine $\left(\mathrm{m}^{6} \mathrm{~A}\right)$ methylated $(15,16)$, and methyltransferase-like (METTL)3/14 promotes their translation, whereas fat mass and obesity-associated (FTO) gene inhibits their translation (15). Both circRNAs and $\mathrm{m}^{6} \mathrm{~A}$ participate in RNA processing, and both are associated with 
AML. Therefore, the aim of the present review is to report the role of canonical epigenetic effects in AML, summarize the progress of RNA epigenetics and circRNAs, and propose a possible link between AML and circRNA epigenetic modifications.

\section{AML and canonical epigenetics}

Epigenetic modifications are associated with numerous important biological processes and serve key roles in the development of an organism. Through epigenetic modifications, cells that bear a similar genome can differentiate into various cell types with different functions (17). The treatment of hematological malignancies, including AML, is challenging. Hence, studies on the association between AML and epigenetics may contribute to elucidating the pathogenesis of this disease. The conventional epigenetic processes include histone modification, chromatin remodeling and DNA methylation. In this section, the role of these epigenetic processes in AML pathogenesis is examined.

AML and DNA methylation. DNA methylation plays a key role in mammalian development (18). As a covalent alteration of genomic DNA, DNA methylation participates in gene expression modification and is involved in the transmission and perpetuation of epigenetic information via DNA replication and cell division (19). Two such functions that are linked to DNA methylation are regulation of genomic stability and gene expression control from the promoter region or another regulatory region containing $\mathrm{CpG}$-rich regions, known as $\mathrm{CpG}$ islands (CGI) (20-22). Several studies involving knockout mouse models of DNA methylation enzymes have demonstrated the importance of DNA methylation in hematopoiesis. Hematopoietic stem cell (HSC) self-renewal, homing and apoptosis suppression have all been shown to require the maintenance of DNA-methyltra nsferase (DNMT)1 $(18,23)$. Furthermore, DNMT1 plays a role in myeloid/lymphoid lineage commitment regulation (23), and multiple studies found that myeloid-specific loci were hypermethylated in lymphoid progenitors (24-26), substantiating this hypothesis. Conditional knockout HSC models confirmed that de novo DNMT3A and DNMT3B served a role in hematopoiesis (27).

Genetic and epigenetic changes are involved in the pathogenesis of AML $(28,29)$, and aberrant DNA methylation patterns have been identified in various types of cancer (30). It was previously reported that dysregulation of DNA methylation is linked to hematological malignancies, suggesting that different subtypes of AML have different DNA methylation profiles (31). Furthermore, promyelocytic leukemia protein-retinoic acid receptor $\alpha(\operatorname{PML}-\mathrm{RAR} \alpha)$ was shown to require DNMT3A to function as an oncogenic transcription factor in acute promyelocytic leukemia initiation, and DNMT3A DNA methyltransferase activity was confirmed to be essential for the enhanced self-renewal of PML-RAR $\alpha$-transformed hematopoietic progenitors (32). Previously, DNMT3A mutations have been identified in $\sim 20 \%$ of AML cases and are associated with poor clinical outcomes, including shorter overall survival (OS) and/or disease-free survival (33-35). Furthermore, Hájková et al (22) reported a possible association between DNA methylation and DNMT3A mutations in patients with AML. DNA methylation levels were significantly lower in patients with mutated DNMT3A, and higher DNA methylation levels were associated with a lower incidence of relapse. The study indicated that patients with lower levels of DNA methylation had a worse OS compared to those with higher DNA methylation levels at multiple loci. Another previous study involving an analysis assay revealed a distinct significant hypomethylation profile in patients with AML with 11q23 abnormalities (31). Moreover, mixed lineage leukemia (MLL)-AF9 overexpression in human hematopoietic stem and progenitor cells (HSPCs) leads to a DNA methylation signature that was found to be similar to that of patients with MLL-AF9 AML (36), suggesting that the leukemic transformation could be due to a possible link between the MLL fusion protein and aberrant DNA methylation. Interestingly, patients with AML harboring various cytogenetic or genetic alterations have also been shown to possess distinct global patterns of DNA methylation, and PML-RAR $\alpha$ and AML1-eight-twenty one (ETO) exhibit highly distinct profiles of methylation $(31,33,37)$. As a result, DNA methylation may be considered as an additional parameter in stratifying patients with AML.

AML and TET2 mutations. Another important group of epigenetic regulators involved in hematopoietic development is the ten-eleven translocation (TET) protein family. TET1 is commonly expressed in embryonic stem cells, whereas TET2 and TET3 are found in most adult tissues (38). TET2 is the most commonly expressed of the three TET family members in the hematopoietic lineage, and it is frequently mutated in hematological malignancies. Tet 2 knockout mice developed splenomegaly, monocytosis and extramedullary hematopoiesis as a result of bone marrow defects with enlargement of the HSC compartment (39). HSCs with Tet2 deletion exhibited increased self-renewal capacity, allowing them to outcompete wild-type counterparts and predominate in the transplanted mice's peripheral blood (40). Furthermore, Tet2-/-HSCs showed a transcriptional program similar to that of common myeloid progenitors, but with enhanced expression of self-renewal regulators Meis1 and Evi1, and decreased expression of myeloid-specific factors Cebpa, Mpo and Csf1 (40). These findings suggested that TET2 is vital for HSC self-renewal and differentiation into the myeloid lineage $(39,40)$.

TET2 is commonly found to be aberrantly expressed in AML, myelodysplastic syndromes/myeloproliferative neoplasms and chronic myelomonocytic leukemia $(41,42)$. Approximately $17 \%$ of patients with AML have loss-of-function mutations of TET2 (43). TET2 mutations can predispose HSCs to a pre-leukemic state, in which they retain the ability to differentiate to a wide range of mature blood cells. However, after acquiring additional genetic lesions, these pre-leukemic stem cells may transform into leukemia-initiating cells $(44,45)$. This suggests that while TET 2 mutations can promote leukemic transformation, they are insufficient for completing the process. TET2 mutations frequently co-occur with other mutations in KRAS, CCAAT enhancer-binding protein $\alpha$, AML1, nucleophosmin 1, FMS-like tyrosine kinase 3 (FLT3) and Janus kinase 2 in AML (46), suggesting that TET2 inactivation works in tandem with these other mutations to drive leukemogenesis. The findings that the synergistic action of 
TET2 depletion and FLT3-internal tandem duplication (ITD) mutation dysregulates DNA methylation and interferes with normal hematopoietic cell differentiation, leading to HSPC and granulocyte-monocyte progenitor accumulation (47), further substantiates this hypothesis. Several hypermethylated regions of TET2 and FLT3-ITD mutations are located at gene regulatory elements, triggering the deregulation of self-renewal and differentiation genes (Gata1, Gata2, inhibitor of differentiation 1, myeloproliferative leukemia virus 1 and suppressor of cytokine signaling 2) (47). Furthermore, knocking out TET2 in pre-leukemic cells with AML1-ETO yielded genome-wide DNA hypermethylation, affecting $\sim 25 \%$ of enhancer elements (48). As several hypermethylated enhancers are linked to tumor suppressor genes, this suggests that TET2 mutations play a role in leukemia development through an epigenetic mechanism.

AML and histone modification. The structural unit of chromatin is a nucleosome consisting of one $\mathrm{H} 1$, two $\mathrm{H} 2 \mathrm{~A}$ and $\mathrm{H} 2 \mathrm{~B}$ dimers, and one $\mathrm{H} 3 / \mathrm{H} 4$ tetramer (49). Histone modification, which is a set of covalent post-translational modifications of histone proteins and modifications that commonly involve acetylation, methylation, phosphorylation, sumoylation, ubiquitination and ADP-ribosylation (49), has been shown to play a role in stem cell differentiation (50). For example, class I and II histone deacetylases (HDACs) that contain the two catalytic domains, function as the mammalian regulators of histone acetylation $(50,51)$.

DNA methylation and histone modification are significant epigenetic mechanisms for gene expression. DNA hypermethylation in the promoter CGIs of tumor suppressor genes that trigger transcriptional silencing is considered to be essential in carcinogenesis (52-54). Histone proteins are assembled into nucleosomes that act as both transcriptional regulators and DNA packaging units. The histone amino-terminal tails protrude from the nucleosome and are subject to chemical modifications, such as acetylation, phosphorylation and methylation (55). Modifications to the post-translational histone tail, added or removed by histone-modifying proteins (HMPs), serve to control access to the underlying DNA and alter gene expression by affecting the structure of chromatin. It has been shown that altered HMP activity contributes to leukemogenesis in AML via gene transcription regulation and, since modifications of post-translational histones are reversible, they may be considered as possible therapeutic targets (56). In addition, removal of the H3K4 methyl group via lysine-specific histone demethylase $1 \mathrm{~A}$ resulted in decreased expression of the tumor suppressor gene. Similarly, the aberrant recruitment of HDACs to promoters of hematopoietic genes was found in AML (56).

AML and chromatin remodeling. Chromatin remodeling is the chromatin architectural modification that controls transcription through nucleosome displacement and rearrangement. The chromatin remodeling mechanism is powered by ATP (57), and chromatin remodeling complexes comprise four main classes as follows: Imitation SWI, switch/sucrose non-fermentable, INO80 complex ATPase subunit and chromodomain-helicase-DNA-binding protein Mi-2 homolog (Mi2/CHDD) $(58,59)$. Chromatin remodeling is fundamental to transcription. Redner et al (60) outlined models of the normal control of chromatin remodeling during gene-specific transcription, and concluded that disruption of these mechanisms may lead to transcriptional disorders and leukemic transformation. They further suggested that chromatin therapy may emerge as a potential antileukemic strategy in the future. In addition, chromatin remodeler inhibition was reported to reduce the development of AML and sensitize AML cells to genotoxic drugs through increased DNA accessibility and impaired double-strand break repair (61).

The chromodomain-helicase-DNA-binding protein 4 (CHD4), an ATP-dependent chromatin remodeling factor, is part of the nucleosome remodeling and histone deacetylation nucleosome remodeling deacetylase complex and plays an important role in the regulation of epigenetic transcriptional genes (62). CHD4 has been associated with oncogenic processes, including cell cycle progression regulation (63-65), cancer metastasis, epithelial-to-mesenchymal transition, and epigenetic repression of tumor suppressor genes (66). Heshmati et al (67) indicated that CHD4 is important for the proliferation of different types of leukemic cells and AML development in vivo, but not for normal primary hematopoietic cell proliferation and survival. It was also confirmed that CHD4 was previously shown to be important for the proliferation of a broad range of cancer cells (67), as well as the capacity of AML cells to form colonies (61), suggesting that CHD4 may represent a cancer-specific dependency in a wider tumor repertoire. In another study, the activity of chromodomain-helicase DNA-binding protein-7 (CHD7), an ATP-dependent chromatin remodeling factor, was found to interact with the AML1/CBF $\beta$-SMMHC complex and altering the expression of its target genes. Chd7 deficiency in Chd7f/fMx1-CreCbfb+/56M mice expressing the Cbfb-MYH11 fusion gene delayed Cbfb-MYH11-induced leukemia in both primary and transplanted mice (68).

One mechanism via which miRNA dysregulation causes AML is epigenetic alterations by altered expression of transcription factors or oncogenic fusion proteins. Of note, the expression of AML1-ETO causes heterochromatic silencing of genomic regions that produce miR-223 by recruiting chromatin remodeling enzymes at the (Runt-related transcription factor 1) RUNX1-binding site of the pre-miR-223 gene (69). Furthermore, AML1-ETO induces heterochromatic silencing at the RUNX1-binding sites of miR-193a by recruiting chromatin remodeling enzymes and expanding the oncogenic function of the fusion protein (70). Taken together, these data demonstrated that chromatin remodeling may be crucial for leukemogenesis, including AML, and may influence its pathogenesis to a certain extent.

\section{RNA modification}

Epigenomics involves stable and inheritable gene expression variations without changes to the sequence of DNA (71). However, epigenetic changes occur in DNA as well as in RNA, termed the epitranscriptome; $>100$ forms of RNA modifications are involved in the epitranscriptome (72), and previous studies have identified RNA modifications mostly in transfer (t)RNAs, ribosomal (r)RNAs and small nuclear (sn)RNAs, whereas they are relatively infrequent in mRNAs $(72,73)$. 
However, technological advancements have been made in the last few years, increasing our ability to recognize alterations to the mRNA, and recent cellular transcriptome studies have focused attention on epitranscription (74). Numerous studies indicate that these modifications significantly enhance the role of RNA in promoting genetic diversity (71-73), and the common RNA modifications consist of $\mathrm{N}^{1}$-methyladenosine, pseudouridine, 5-methylcytosine $\left(\mathrm{m}^{5} \mathrm{C}\right)$, 7-methylguanosine, $\mathrm{m}^{6} \mathrm{~A}$ and 2'-O-ribosemethylation $(72,75)$. The most common types of RNA epigenetic modifications are summarized in this review.

\section{4. $\mathrm{m}^{6} \mathrm{~A}$ modification}

One of the most common mRNA modifications identified in all eukaryotes is the $\mathrm{m}^{6} \mathrm{~A}$ modification, which is the methylation of position N6 of adenosine (76). To detect this alteration, earlier studies used mass spectrometry and showed that the relative content of $\mathrm{m}^{6} \mathrm{~A}$ ranged from 0.1 to $0.4 \%$, representing the modification of $3-5$ sites in each mRNA $(73,76)$. The $\mathrm{m}^{6} \mathrm{~A}$ modification, which is decoded by $\mathrm{m}^{6} \mathrm{~A}$ methyltransferase post-transcriptionally, is an abundant internal modification in eukaryotic mRNA (77) and often occurs in the RRACH $(\mathrm{R}=\mathrm{G}$ or $\mathrm{A} ; \mathrm{H}=\mathrm{A}, \mathrm{C}$ or $\mathrm{U}$ ) consensus sequence (78). The $\mathrm{m}^{6} \mathrm{~A}$-specific MeRIP-Seq method was previously used to detect and analyze the position of $\mathrm{m}^{6} \mathrm{~A}$, which was found to be localized predominantly in the $3^{\prime}$ untranslated regions (UTRs) of mRNAs, long internal exons and stop codons (79). The distribution of $\mathrm{m}^{6} \mathrm{~A}$ in tissue-specific sites was also analyzed, and this modification was found to be abundant in the heart, brain and kidney (79).

Another study used an $\mathrm{m}^{6} \mathrm{~A}-\mathrm{Seq}$ method and detected that the sites modified by $\mathrm{m}^{6} \mathrm{~A}$ are highly conserved in humans and mice (80). To increase the resolution of $\mathrm{m}^{6} \mathrm{~A}$ detection, researchers have developed antibody-based crosslinking methods (76-79). The terms 'writer', 'eraser' and 'readers' are used to accurately characterize the $\mathrm{m}^{6} \mathrm{~A}$ activity, and these terms are commonly used for other types of modifications as well. METTL3, METTL14 and the regulatory subunit Wilms tumor 1 associated protein (WTAP) constitute the $\mathrm{m}^{6} \mathrm{~A}$ methyltransferase (81-83). METTL14 exerts its enzymatic activity by interacting with METTL3 to methylate the conserved GGACU and GGAUU sequences (84). Although it does not have methyltransferase activity due to the lack of a catalytic center, by interacting with METTL3 and METTL14, WTAP may locate the methyltransferase complex into nuclear speckles (85). METTL3 knockdown was shown to induce alterations in splicing patterns and alternative polyadenylation that affected RNA stability, transcriptional silencing and translation (86-91). A study previously detected another mechanism of $\mathrm{m}^{6} \mathrm{~A}$ modification: METTL16, a long unknown U6 small nucleolar (sn)RNA methyltransferase capable of controlling S-adenosylmethionine levels that affect $\mathrm{m}^{6} \mathrm{~A}$ levels in most cells by controlling human MAT2A expression (92).

The identification of $\mathrm{m}^{6} \mathrm{~A}$ demethylating enzymes, known as 'erasers', focused on the FTO (93) and AlkB homolog 5, RNA demethylase (ALKBH5) proteins, belonging to the $\mathrm{Fe}(\mathrm{II})$ and 2-oxoglutarate-dependent oxygenase superfamily $(94,95)$, and they oxidize $\mathrm{m}^{6} \mathrm{~A}$ via N6-hydroxymethyladenosine $\left(\mathrm{hm}^{6} \mathrm{~A}\right)$ and N6-formyladenosine ( $\left.\mathrm{f}^{6} \mathrm{~A}\right)$ intermediates (96). It was previously indicated that FTO is involved in several essential life processes, including adipogenesis (97), the regulation of brain dopaminergic signaling (98), adipogenetic regulatory factor mRNA splicing (99) and the enhancement of the transformation and leukemogenesis of leukemic oncogene-mediated cells (100). FTO and ALKBH5 are both essential for cells, and these demethylating enzymes also influence mRNA processing, nuclear export and metabolism in HeLa cells (94). Furthermore, it was previously reported that the development of cancer stem cells is driven by ALKBH5 and the depletion of $\mathrm{m}^{6} \mathrm{~A}(101)$.

The $\mathrm{m}^{6} \mathrm{~A}$ effector proteins known as 'readers' involve the YT521-B homology (YTH) family that encodes in mammals five proteins, namely the YTH domain family (YTHDF) proteins 1, 2 and 3, and the YTH domain-containing (YTHDC) proteins 1 and $2(99,101)$. To date, four of these proteins have been shown in vitro and in vivo to display $\mathrm{m}^{6} \mathrm{~A}$ selectivity $(102,103,104)$. YTHDF2 and YTHDC1 have an $\mathrm{m}^{6} \mathrm{~A}$-specific conserved hydrophobic binding pocket and are involved in the mechanism controlling the methylation and transcript fate of mRNA $(102,104,105)$. Furthermore, the high-resolution mapping of transcription-binding sites has shown that YTHDF1 and YTHDF2 tend to bind to the GGACU conserved mRNA sequence motif, which shows significant overlap with $\mathrm{m}^{6} \mathrm{~A}$ methylation sites $(103,106,107)$.

During the development of an organism, N6-methyladenosine plays a critical role, and changes in $\mathrm{m}^{6} \mathrm{~A}$ levels affect several life processes, including tissue development, self-renewal $(96,108)$ and differentiation of stem cells $(99)$. $\mathrm{m}^{6} \mathrm{~A}$ can also regulate the heat shock response (91), circadian clocks (98), as well as processes related to the fate and function of RNAs, such as RNA stability, splicing, transport, localization and translation $(89,90,96,102,107,108)$, primary processing of miRNAs $(109,110)$ and RNA-protein interactions $(80,81,111)$. A substantial body of research however, suggests a link between $\mathrm{m}^{6} \mathrm{~A}$ and certain diseases, including AML. $\mathrm{m}^{6} \mathrm{~A}$ has been associated with obesity, diabetes and cancer (112). $\mathrm{m}^{6} \mathrm{~A}$ modifications may be used in combination with tumor therapy. A study analyzed The Cancer Genome Atlas (TCGA) datasets and discovered that changes in $\mathrm{m}^{6} \mathrm{~A}$ regulatory genes were linked to TP53 mutations in patients with AML. Moreover, alterations in the $\mathrm{m}^{6} \mathrm{~A}$ regulatory genes were found to lower the survival rates of patients with AML. Therefore, $\mathrm{m}^{6} \mathrm{~A}$ regulatory genes may serve as potential new molecular targets for AML therapy (113). In addition, Su et al (114) reported the antitumor activity of R-2-hydroxyglutarate in patients with AML harboring an isocitrate dehydrogenase (IDH) mutation by blocking FTO to induce MYC degradation. In tissue cells with an IDH mutation, TCGA data showed high MYC and low FTO levels. Numerous studies have recently investigated the regulation of mRNA metabolism by $\mathrm{m}^{6} \mathrm{~A}$ modifications, revealing $\mathrm{m}^{6} \mathrm{~A}$ modification characteristics and associated regulatory mechanisms in AML (Table I) $(100,115,116)$.

\section{Other RNA modifications}

DNA has been the subject of the majority of studies on $\mathrm{m}^{5} \mathrm{C}$, and $\mathrm{m}^{5} \mathrm{C}$ is not frequently found in RNA (84). Researchers have found however, that $\mathrm{m}^{5} \mathrm{C}$ is enriched in $3^{\prime}$-UTRs (117). 3-Methylcytidine $\left(\mathrm{m}^{3} \mathrm{C}\right)$ was first detected in Saccharomyces cerevisiae total RNA (118). Previous findings demonstrated 
Table I. Roles of some $\mathrm{m}^{6} \mathrm{~A}$ key members in AML.

\begin{tabular}{|c|c|c|c|c|c|}
\hline First author, year & Protein & Role & Functional classification & Mechanism & (Refs.) \\
\hline Vu et al, 2017 & METTL3 & Oncogene & $\begin{array}{l}\text { Inhibiting differentiation along with } \\
\text { promoting cell growth in vitro } \\
\text { Inducing differentiation and apoptosis, } \\
\text { and preventing leukemia in vivo }\end{array}$ & $\begin{array}{l}\text { Promotes c-MYC, BCL2 } \\
\text { and PTEN translation }\end{array}$ & $(115)$ \\
\hline Weng et al, 2018 & METTL14 & Oncogene & $\begin{array}{l}\text { Inhibiting differentiation of AML. } \\
\text { Promoting leukemia stem cell } \\
\text { self-renewal }\end{array}$ & $\begin{array}{l}\text { Regulates the stability of } \\
\text { mRNA as well as MYB } \\
\text { and MYC translation, and } \\
\text { was inhibited by SPI1 }\end{array}$ & $(116)$ \\
\hline Li et al, 2017 & $\begin{array}{l}\text { Fat mass } \\
\text { and obesity- } \\
\text { associated }\end{array}$ & Oncogene & $\begin{array}{l}\text { Promotes cell transformation together } \\
\text { with leukemogenesis, enhancing } \\
\text { the inhibition of cell differentiation } \\
\text { in AML }\end{array}$ & $\begin{array}{l}\text { Regulates the expression } \\
\text { of targets like ASB } 2 \text { and } \\
\text { RAR } \alpha \text { by decreasing } \mathrm{m}^{6} \mathrm{~A} \\
\text { levels in these mRNA } \\
\text { transcripts }\end{array}$ & $(100)$ \\
\hline
\end{tabular}

AML, acute myeloid leukemia; METTL, methyltransferase-like; SPI1, transcription factor PU.1; ASB2, Ankyrin repeat and SOCS box protein 2; RAR $\alpha$, retinoic acid receptor $\alpha$; PTEN, phosphatase and tensin homolog.

that METTL2 and METTL6 participate in $\mathrm{m}^{3} \mathrm{C}$ modifications, in particular in TRNAs, and that METTL8 only causes $\mathrm{m}^{3} \mathrm{C}$ changes in mRNA in humans and mice (119). Another study identified RNA methylation in mixtures of either RNA isomers or non-isomeric RNA types and detected modifications in RNA methylation, such as 3-methyluridine, $\mathrm{m}^{5} \mathrm{C}, \mathrm{m}^{6} \mathrm{~A}$ and 5-methyluridine, by top-down mass spectrometry (120). A relatively abundant form of RNA modification is also pseudouridylation, and the relative amount of pseudouridine in RNA is $0.2-0.6 \%$ (121). Two mechanisms are involved in the formation of pseudouridine: One is dependent on tRNA-pseudouridine synthase (PUS)I, whereas the other relies on a type of H/ACA box small nucleolar RNA $(122,123)$. In rRNA, pseudouridine is mainly found in peptidyl transferase centers, decoding centers and the A-site finger region (124). This modification may therefore be involved in rRNA processing, ribosome assembly, as well as advanced structure maintenance (125). It has been shown that pseudouridine is highly conserved in snRNA (U1, U2, U3, U4, U5 and U6) in various species (126). In 2011, a study showed that, through pseudouridylation, stop codons may be transformed into sense codons (127). HSPCs are also particularly sensitive to changes in pseudouridine and protein synthesis. In this regard, silencing PUS7 causes a decrease in a specific type of tRNA-derived small fragment containing 5' terminal oligoguanine (mTOG), resulting in increased protein synthesis and severe HSPC differentiation blockage (128). Protein synthesis is disrupted in patients with myelodysplastic syndrome due to PUS7 and mTOGs dysfunction, which is characterized by a high rate of transformation to aggressive leukemia (128). The irreversible deamination of adenosine to inosine, known as A-to-I editing, is another commonly studied RNA modification. Inosine is a normal and necessary post-transcriptional modification of the RNA introduced by specific deaminases (129) and this process is catalyzed by adenosine deaminase acting on tRNA, while adenosine deaminase acting on RNA catalyzes the process in mRNAs and non-coding RNAs (130). Hematopoiesis involves A-to-I RNA editing. During myeloid differentiation, adenosine deaminases that act on RNA (ADAR)1 and ADAR2 are modulated. ADAR1 expression was shown to be upregulated in AML and was linked to the proliferation of leukemia cells. Silencing ADAR1 promoted AML cell cycle arrest and reduced Wnt effector expression (128). The alteration in the splicing pattern of protein tyrosine phosphatase non-receptor type 6 and its association with leukemogenesis is another example of the effect of RNA editing in AML (128).

\section{Epigenetic modifications of circRNAs}

circRNAs are an abundant class of RNA species formed from the ligation of a downstream splice donor to an upstream acceptor. They have a cyclically ordered structure, and are involved in a variety of physiological and pathological processes $(4,131)$, have structural stability, sequence conservation and tissue-specific expression. circRNAs have more recently become one of the most frequently studied RNA species. Due to the aforementioned unique characteristics, circRNAs are known to act as miRNA sponges $(4,11)$, and they are capable of being translated into proteins through an internal ribosome entry site (IRES)-driven process (132). Furthermore, several circRNAs have been suggested to serve as potential biomarkers for several diseases, including several types of cancer (14). Although numerous biological functions of circRNAs remain unclear, there is a continuous exploration of this research field. In 2017, circRNAs were identified to be widely methylated by $\mathrm{m}^{6} \mathrm{~A}$, and this was determined by $\mathrm{m}^{6} \mathrm{~A}$ immunoprecipitation of RNase R exoribonuclease-treated RNA samples, and they were effectively translated as IRESs in human cells via short sequences consisting of the $\mathrm{m}^{6} \mathrm{~A}$ site (15). Initiation of this $\mathrm{m}^{6} \mathrm{~A}$-mediated translation involves the eukaryotic translation initiation factor $4 \mathrm{G} 2$ and a $\mathrm{YTH}$ m6A RNA-binding protein (YTHDF)3 reader, and their mechanism of translation involves METTL3/14 and is inhibited by FTO (Fig. 1). In addition, that study detected that when 


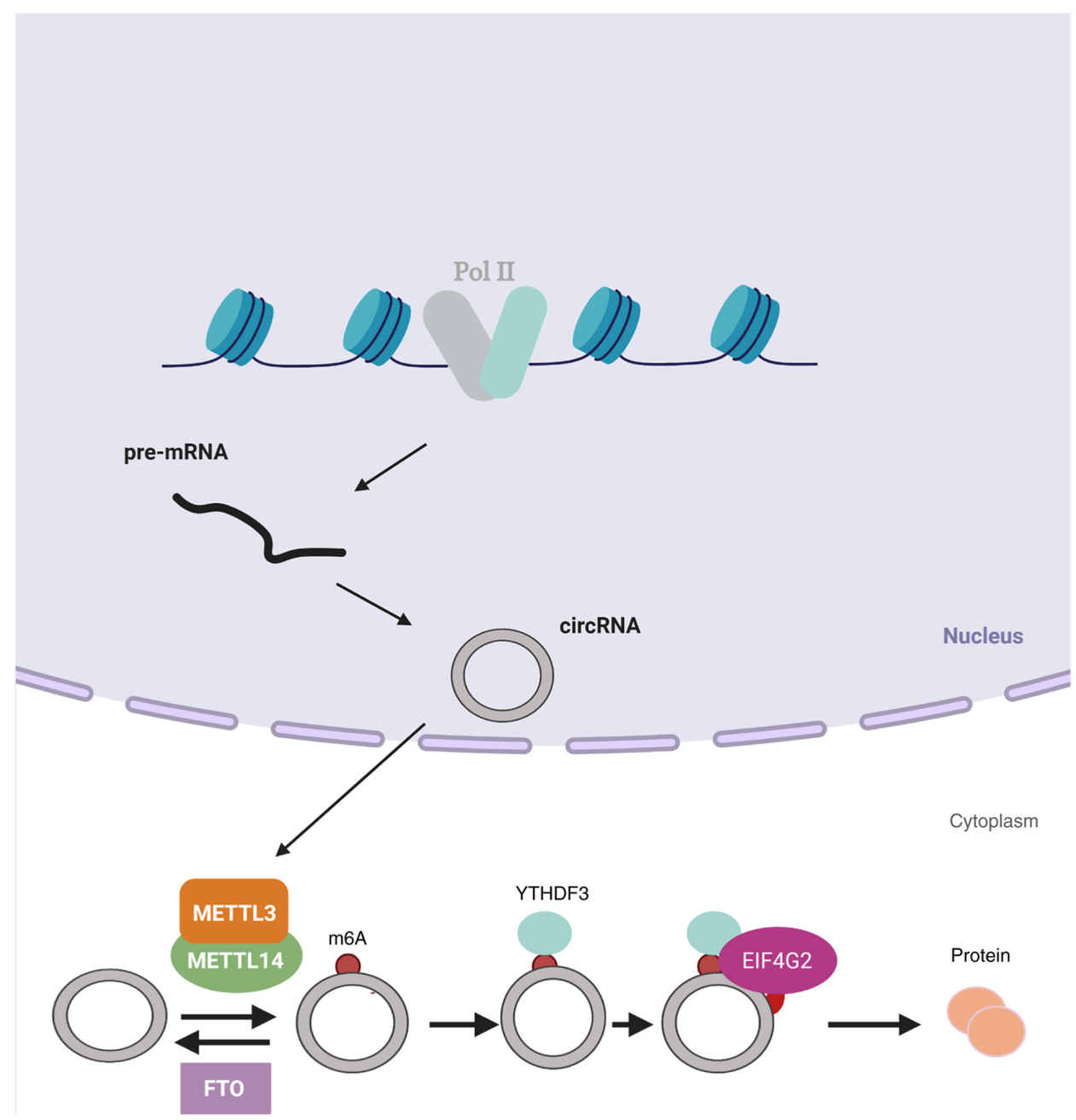

Figure 1. Regulation of circRNAs by $\mathrm{m}^{6} \mathrm{~A}$ modifications. The cytoplasm is where $\mathrm{m}^{6} \mathrm{~A}$ modifications affect circRNA via a regulatory mechanism. The demethylase FTO and methyltransferase complex METTL3/14 regulate circRNA. The METTL3/14 methyltransferase complex induces circRNA m ${ }^{6} \mathrm{~A}$ methylation modifications, whereas the FTO demethylase removes circRNA $\mathrm{m}^{6} \mathrm{~A}$ methylation. The $\mathrm{m}^{6} \mathrm{~A}$ methylation site is recognized by YTHDF3, which then recruits eIF4G2 to the circRNA, resulting in circRNA translation. As a result, $\mathrm{m}^{6} \mathrm{~A}$ can modify circRNAs, and the methylated circRNAs can encode proteins circRNA, circular RNA; FTO, fat mass and obesity-associated; METTL, methyl transferase-like; YTHDF3, YTH domain family protein 3; eIF4G2, Eukaryotic translation initiation factor $4 \gamma 2$.

circRNAs were subjected to heat, their translational function improved, suggesting that circRNA-encoded proteins may be essential under conditions of stress (15). Other researchers also built an AutoCirc computational pipeline to analyze RNA and $\mathrm{m}^{6} \mathrm{~A}$ immunoprecipitation results, and further confirmed that $\mathrm{m}^{6} \mathrm{~A}$ modifications are largely observed in circRNAs (16). $\mathrm{m}^{6} \mathrm{~A}$ circRNAs were shown to possess highly cell-specific expression, and found that circRNAs with $\mathrm{m}^{6} \mathrm{~A}$ modifications also had long single exons (16). Moreover, $\mathrm{m}^{6} \mathrm{~A}$ circRNAs and $\mathrm{m}^{6} \mathrm{~A}$ mRNAs were compared by the researchers, and it was validated that the methylated exons in mRNAs were distinct from the exons that form $\mathrm{m}^{6} \mathrm{~A}$ circRNAs. In addition, they indicated that $\mathrm{m}^{6} \mathrm{~A}$ circRNAs were correlated with mRNA stability via the interaction with YTHDF1/YTHDF2 (16).

Role of $m^{6} A$ methylation in the regulation of circRNAs. Current RNA research indicates that the dysregulation of $\mathrm{m}^{6} \mathrm{~A}$ modification is linked to various diseases, including cancer. Aberrant $\mathrm{m}^{6} \mathrm{~A}$ modification contributes to tumorigenesis and tumor progression in the majority of cases. Researchers have recently focused their attention on $\mathrm{m}^{6} \mathrm{~A}$-modified $\mathrm{mRNA}$, as $\mathrm{m}^{6} \mathrm{~A}$ functions primarily by influencing RNA metabolism. Currently, $\mathrm{m}^{6} \mathrm{~A}$-modified ncRNAs as well as $\mathrm{m}^{6} \mathrm{~A}$-modified circRNAs, need to be further explored. The role of $\mathrm{m}^{6} \mathrm{~A}$ modification in the regulation and function of circRNA is summarized here.

Studies have revealed that certain circRNAs can encode proteins $(132,133)$ and that $\mathrm{m}^{6} \mathrm{~A}$ can drive the translation process (15). The transcription initiation elements are located on the $5^{\prime}$ end cap structure of mRNA, and the translation mechanism is associated with the transcription initiation elements-cap structure or mechanism (134). In the absence of a dissociative 5 ' end, this traditional cap-dependent mechanism does not function in a closed circular transcript. As a result, some cap-independent translation initiation mechanisms, such as the IRES-dependent and $\mathrm{m}^{6} \mathrm{~A}$-dependent mechanisms, were proposed to explain how some circRNAs can code for proteins. IRESs are sequences that mediate ribosome-RNA binding and, thus, initiate translation. circZNF609 in myogenesis (132), circMbL in fly head extracts (133), circSHPRH and circFBXW7 in glioma tumorigenesis $(135,136)$, and $\operatorname{circ} \beta$-catenin in liver cancer growth (137) are examples 
of protein-coding circRNAs driven by IRESs. A study by Yang et al (15) however, broadened our understanding of the coding landscape of the $\mathrm{m}^{6} \mathrm{~A}$-human transcriptome. In cellular responses to environmental stress, an $\mathrm{m}^{6} \mathrm{~A}$-driven translation pathway was proposed and validated. circRNA $\mathrm{m}^{6} \mathrm{~A}$ containing motifs were found to be translated, and translation efficiency was found to be modulated by the $\mathrm{m}^{6} \mathrm{~A}$ level. It is worth noting that these two cap-independent translation pathways may not function independently. Legnini et al (132) reanalyzed $\mathrm{m}^{6} \mathrm{~A}-\mathrm{Seq}$ and immunoprecipitation (IP) data and combined it with other $\mathrm{m}^{6} \mathrm{~A}$ IP results in myoblasts alone (132). The results revealed that the IRES-activated protein-coding circRNA, circZNF609, exhibited high $\mathrm{m}^{6} \mathrm{~A}$ methylation levels, suggesting a possible link between these two cap-independent pathways.

Circular RNAs are naturally more stable than their parental linear RNAs due to their closed circular structure, as they are not the primary targets of foreign chemicals or exonucleases. This was confirmed in several studies associated with the characterization of circRNAs $(138,139)$. In Actinomycin D and RNase R treatment, circRNAs are rarely degraded before their corresponding parental linear RNAs (140). However, little is known about how circRNAs are degraded and what factors contribute to circRNA degradation. One of the pathways by which $\mathrm{m}^{6} \mathrm{~A}$-modified RNAs are degraded is the endoribonucleolytic cleavage pathway. As emerging research in the field of RNA research, $\mathrm{m}^{6} \mathrm{~A}$-modified circRNAs were also discovered to be endoribonuclease-cleaved via a YTHDF2-HRSP12-RNase P/MRP axis (141). HRSP12 is an adaptor protein that connects YTHDF2 $\left(\mathrm{m}^{6} \mathrm{~A}\right.$ reader protein) and RNase $\mathrm{P} / \mathrm{MRP}$ (endoribonucleases) to form the YTHDF2-HRSP12-RNase P/MRP complex, with YTHDF2 serving as the guide. When an $\mathrm{m}^{6} \mathrm{~A}$-modified circRNA is recognized by YTHDF2, regardless of whether it occupies an HRSP12-binding site, RNase P/MRP always performs its endonuclease function. The only difference is that the presence of the HRSP12 binding site improves endoribonucleolytic cleavage efficiency significantly. The $\mathrm{m}^{6} \mathrm{~A}$-modified circRNA is then selectively downregulated. The biological function of circRNAs is altered as a result (142). Thus, it can be deduced that one of the means by which $\mathrm{m}^{6} \mathrm{~A}$ modification regulates circRNA biological function is by affecting their degradation.

Interesting emerging studies suggest a possible link between $\mathrm{m}^{6} \mathrm{~A}$ modification of circRNAs and certain diseases, including cancer. A recent study suggested $\mathrm{m}^{6} \mathrm{~A}$ modification of human endogenous circRNAs played a key role in the inhibition of innate immunity. This study also indicated that exogenous circRNAs were found to induce antigen-specific $\mathrm{T}$ - and B-cell activation, antibody production and antitumor immunity in vivo, while $\mathrm{m}^{6} \mathrm{~A}$ modifications of these exogenous circRNAs inhibited activation of immunity. Furthermore, YTHDF2 was also suggested to be required for inhibiting innate immunity by recognizing $\mathrm{m}^{6} \mathrm{~A}$ (143). $\mathrm{m}^{6} \mathrm{~A}$ modification was shown to play a key role in stabilizing circCUX1 expression, inhibiting caspase- 1 expression and conferring radiotherapy resistance to hypopharyngeal squamous cell carcinoma (140). Moreover, it was observed that $\mathrm{m}^{6} \mathrm{~A}$ modification facilitated the cytoplasmic export of circNSUN, which promoted colorectal carcinoma metastasis (139). Taken together, these findings suggest that circRNAs may regulate the progression of cancer, possibly including AML, via $\mathrm{m}^{6} \mathrm{~A}$ modification. However, further evidence is required to determine the regulatory mechanisms involved. These findings indicate that the regulatory mechanisms involved in circRNA interaction with $\mathrm{m}^{6} \mathrm{~A}$ members could be essential for cancer progression, which may provide new insights into tumorigenesis.

\section{7. circRNAs and AML}

The accumulation of abnormal and immature hematopoietic progenitor cells (HPCs) in the bone marrow and peripheral blood is caused by a variety of genetic and epigenetic abnormalities that arrest hematopoietic cell differentiation and maturation. Lethal infection, organ infiltration and cytopenias are frequently associated with these abnormalities $(4,9)$. The progression and pathogenesis of hematopoietic malignancies and solid tumors including AML have been linked to aberrant circRNA expression (Table II). This was further validated in a recent study in which hundreds of circRNAs were found to be differentially expressed in AML, and several of these circRNAs were transcribed from genes implicated in leukemia biology (144). miRNAs are short stretches of RNA ( $23 \mathrm{nt}$ in length) that are linked to a variety of biological processes (2), and circRNAs have also been associated with tumorigenesis, metastasis and drug resistance (145). Interestingly, the most well-known mechanism of action of circRNAs is their 'sponge' function, which involves binding to miRNAs $(15,146)$, proteins (139-141) or DNA $(147,148)$. circRNAs modulate mRNA stability and translation by sequestering the mRNA and protein transcripts, and this is the most well-known role of circRNAs in AML $(149,150)$. A brief review of several AML studies suggests that circRNAs could become possible biomarkers in AML (Table II) (150-156). Although the roles of circRNAs in AML requires further exploration, it is evident that circRNA levels are dynamically modulated in AML. Thus, these findings suggest that circRNAs may play an important role in AML.

Sponging interaction with miRNAs and RNA-binding proteins (RBPs). The first function of circRNAs, which was discovered in 2013, was that of miRNA sponging, and the most well-established function of circRNAs is to sponge miRNAs and proteins. ciRS-7 has $>70$ conserved miR-7 binding sites, and it can bind to the Argonaute (AGO) protein $(11,147)$. The sequestration of miRNAs by circRNAs supports the translational machinery to bind to the specific mRNA, resulting in gene derepression in the case of circRNA-miRNA sponge formation (Fig. 2A). Increased expression of genes that are involved in cell proliferation, differentiation and migration may support the development of leukemia (147). Both cis-and trans-acting factors (157), the latter also termed as RBPs, regulate circRNA biogenesis (147). Since RBPs are also involved in cell cycle progression as well as the biogenesis of circRNAs, circRNA-RBP interactions (Fig. 2B) or indirect circRNA-miRNA-RBP interactions by circRNAs may also induce the development of leukemia (158).

With regard to the role of circRNA-miRNA interaction in AML, a study by Wu et al (150) revealed that circDLEU2 suppressed miRNA-496 expression, which has protein kinase 
Table II. List of circRNAs and related miRNA sponges reported in acute myeloid leukemia.

\begin{tabular}{|c|c|c|c|c|c|c|}
\hline First author, year & $\begin{array}{c}\text { Circ base ID } \\
\text { (name of circRNA) }\end{array}$ & $\begin{array}{l}\text { Change in } \\
\text { expression }\end{array}$ & $\begin{array}{l}\text { miRNA target } \\
\text { sponge }\end{array}$ & Functions & Target gene(s) & (Refs.) \\
\hline Ping et al, 2019 & $\begin{array}{l}\text { hsa_circRNA_100053 } \\
\text { (circ_0009910) }\end{array}$ & Up & miR-20a-5p & Biomarker & $\begin{array}{l}\text { RUNX3, } \\
\text { Rab27B, Smad }\end{array}$ & (151) \\
\hline Fan et al, 2018 & hsa_circ_100290 & Up & miR-203 & Oncogene & Rab10 & $(152)$ \\
\hline Chen et al, 2018 & $\begin{array}{l}\text { hsa_circRNA_101141 } \\
\text { (circ-ANAPC7) }\end{array}$ & Up & miR-181 family & $\begin{array}{l}\text { Oncogene, } \\
\text { biomarker }\end{array}$ & Numerous & $(153)$ \\
\hline Wu et al, 2018 & $\begin{array}{l}\text { hsa_circ_0000488 } \\
\text { (circ-DLEU2 ) }\end{array}$ & Up & miR-496 & $\begin{array}{l}\text { Biomarker, } \\
\text { therapeutic } \\
\text { target }\end{array}$ & PRKACB & $(150)$ \\
\hline Li et al, 2017 & hsa_circ_0004277 & Down & $\begin{array}{l}\operatorname{miR}-138-5 p \\
\operatorname{miR}-30 c-1-3 p \\
\operatorname{miR}-892 b\end{array}$ & $\begin{array}{l}\text { Biomarker, } \\
\text { therapeutic } \\
\text { target }\end{array}$ & $\begin{array}{l}\text { SH3GL2, } \\
\text { PPARGC1A }\end{array}$ & (154) \\
\hline Shang et al, 2019 & $\begin{array}{l}\text { hsa_circ_0100181 } \\
\text { (circ-PAN3) }\end{array}$ & Up & $\begin{array}{l}\text { miR-153-5p } \\
\text { miR-183-5p }\end{array}$ & $\begin{array}{l}\text { Drug } \\
\text { resistance }\end{array}$ & XIAP & $(155)$ \\
\hline Hirsch et al, 2017 & $\begin{array}{l}\text { hsa_circ_0075001 } \\
\text { (circNPM1) }\end{array}$ & Up & miR-181 & Biomarker & $\begin{array}{l}\text { TLR signaling } \\
\text { pathway genes }\end{array}$ & (156) \\
\hline
\end{tabular}

circRNA, circular RNA; miRNA/miR, microRNA.

cAMP-activated catalytic subunit $\beta$ (PRKACB) as a downstream target gene (Fig. 3A). PRKACB encodes the catalytic subunit of the cyclic AMP-dependent protein kinase, which uses cAMP to regulate various signaling processes, such as proliferation and differentiation. miR-496 inhibited PRKACB expression, whereas circ-DLEU2 sponging miR-496 increased PRKACB expression. As a result, increased circ-DLEU2 expression promoted leukemic cell proliferation and inhibited apoptosis in vitro, and promoted the formation of AML tumors in vivo. These findings suggested that circ-DLEU2 may be essential for the development of AML (150).

The interaction between circRNAs and RBPs, as well as the associated potential functional aspects, are becoming increasingly clear (159). AGO $(4,11)$, RNA polymerase II (9), Muscleblind protein (12), Quaking I (147) and elongation initiation factor 4A3 (160) are some of the RBPs that have been identified. These RBPs play a role in cellular processes by regulating gene expression. Some upregulated interacting RBPs serve key roles in RNA splicing and maintaining the leukemic condition, according to CRISPR-Cas9-based RBP screening in AML. When RBM39, the network's main regulator, is knocked out, the splicing of essential mRNAs for AML is disrupted, resulting in AML cell apoptosis (161). Furthermore, as comprehensively reviewed previously (162), mutational profiling of leukemic patients has revealed somatic genetic mutations in RBPs that are linked to splicing. In addition, in patients with AML with ITD mutations in the FLT3 gene, high expression of circMyb-related protein B (MYBL2), a product of the MYBL2 gene, was reported. The circMYBL2 and FLT3-ITD mutant kinase were found to have a positive regulatory relationship. circMYBL2 was identified to improve mutant FLT3 kinase protein expression, as a result, FLT3-ITD-dependent signaling pathways were activated.
circMYBL2 enhanced FLT3 kinase translational efficiency by promoting the binding of polypyrimidine tract-binding protein 1 (PTBP1) to mutant FLT3 kinase mRNA. In addition to inhibiting AML cell proliferation and supporting differentiation in vitro and in vivo, circMYBL2 knockdown compromised the cytoactivity of cells with the FLT3-ITD mutation against quizartinib (Fig. 3B) (163).

Regulation of gene transcription. circRNAs are primarily located in the cytoplasm due to their stable structure, nonetheless, some circular isoforms (EIcircRNA) can also be found in the nucleus. These circular isoforms bind to chromatin modifiers, causing the gene to be repressed or activated $(164,165)$. RNA polymerase II interacts with certain EIcircRNAs, such as circEIF3J and circPAIP2, to recruit U1 small nuclear ribonucleoprotein to promote gene transcription (13). Furthermore, some circRNAs positively regulate the expression of their parent gene, as seen in the case of circRNA, ci-ankrd52, which reduces the expression of ankrd52 without affecting the expression of the surrounding genes (9). By binding to its cognate DNA, circRNA derived from the SEP3 gene controls expression of the linear transcript. circRNA-SEP3 has a linear counterpart with the same sequence that binds to DNA with a low affinity. Hence, transcriptional repression together with the generation of a SEP3 linear transcript with exon skipping are likely outcomes of circRNA-DNA formation (166). Furthermore, promoter-associated RNA suppresses rRNA gene expression by recruiting DNMT3b to the TTF-I (transcription factor) target site via complementarity with the rDNA promoter. By binding to genomic DNA and forming a DNA-RNA triplex, the circRNA, like other RNA species, may affect DNA replication (167). These findings suggest that circRNAs may bind to DNA to regulate gene expression and DNA replication. 


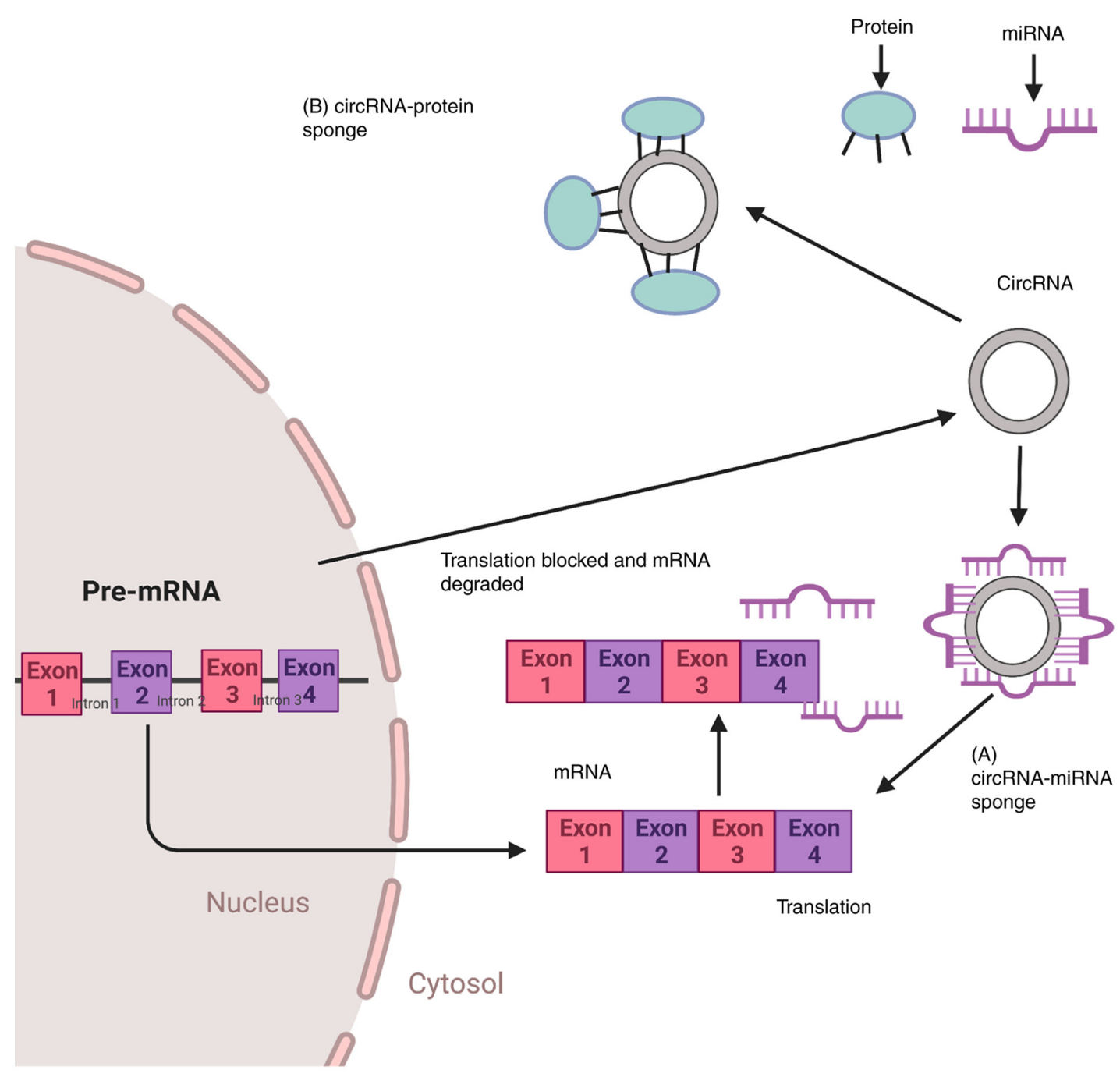

Figure 2. circRNAs sponging interactions with miRNAs and RBPs. (A) circRNAs act as miRNA sponges to regulate mRNA translation. circRNAs may act as miRNA sponges to compete for miRNA binding sites and thus reducing the impact of miRNA-mediated regulatory functions. (B) circRNA may sponge with proteins (RBP) that regulate gene expression and thus play a role in a variety of biological processes. circular RNA; miRNA, microRNA; RBP, RNA binding protein.

Translation. Even though circRNAs have an open reading frame, they often lack essential translational components, such as a poly(A) tail and a 7-methylguanosine cap (133). Nonetheless, mounting evidence suggests that circRNAs are capable of translation (133). For example, the RNA modification motif $\mathrm{m}^{6} \mathrm{~A}$, which is abundantly present in circRNAs, aids circRNA translation in human cells (15). Other mechanisms exist for circRNA translation. circRNAs containing an IRES which drives translation, such as circ-ZNF609 and circMbl3, have been found to translate proteins $(132,133)$. Furthermore, Sun et al $(163)$ suggested that circMYBL2 regulated FLT3 translation by recruiting PTBP1 to enhance FLT3-ITD AML progression. Generally, circRNA translational mechanisms in AML are not well understood and require further investigation.

\section{8. circRNA epigenetic modifications and their possible roles in AML}

$\mathrm{m}^{6} \mathrm{~A}$ is one of the most abundant patterns of methylation in mRNAs, and was also previously detected in circRNAs, as described above $(15,16)$. It was further demonstrated that $\mathrm{m}^{6} \mathrm{~A}$ is important for the regulation of the fate and function of RNA, which are essential for differentiation and development (99). In addition, FTO, as an $\mathrm{m}^{6} \mathrm{~A}$ demethylating enzyme, was found to be overexpressed and to play a critical oncogenic role in AML by promoting cell transformation and leukemogenesis, and inhibiting cell differentiation (100).

By acting as miRNA sponges, circRNAs are involved in regulating RNA processing, such as alternative splicing, pre-RNA splicing and RNA editing $(11,168,169)$. Furthermore, aberrant circRNA expression (mainly upregulation), has been identified as a potential biomarker in AML (Table II). The mechanisms by which circRNAs regulate AML remains unclear. Previous findings suggest that circRNAs may regulate tumorigenesis, at least partly via $\mathrm{m}^{6} \mathrm{~A}$ modification $(139,140,143)$.

$\mathrm{m}^{6} \mathrm{~A}$ regulators have been identified to be responsible for the dysregulation of $\mathrm{m}^{6} \mathrm{~A}$ epigenetic modifications in circRNAs. One such regulator, METTL3, was found to induce circ1662 expression by introducing $\mathrm{m}^{6} \mathrm{~A}$ modifications in circ1662 flanking reverse complementary sequences. 
(A) circDLEU2

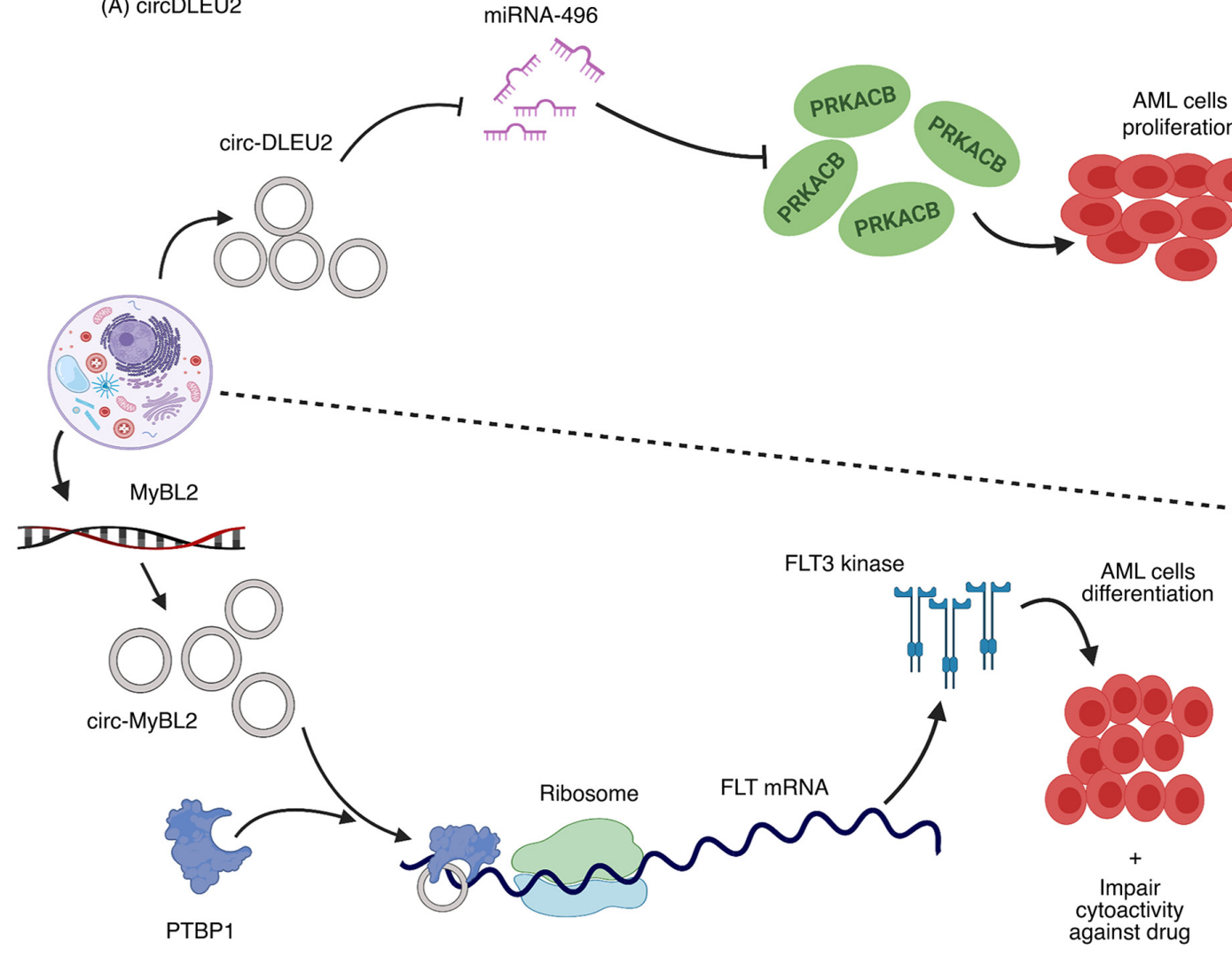

(B) circMYBL2

Figure 3. Potential mechanisms of circRNAs in AML. (A) miRNA-496 binds to the related mRNA sites, leading to PRKACB repression; however, circDLEU2-miRNA-496 sponge formation supports the translational machinery to bind to the mRNA, resulting in gene derepression. AML cell proliferation is linked to increased PRKACB expression. (B) The recruitment of PTBP1 to the FLT3-ITD in an mRNA transcript, circMYBL2, which is derived from the MYBL2 gene, positively regulates the FLT3-ITD mutant gene's expression. AML, acute myeloid leukemia; miRNA, microRNA; PRKACB, cAMP-dependent protein kinase catalytic subunit $\beta$; PTBP1, polypyrimidine tract-binding protein 1; FLT3-ITD, FMS-like tyrosine kinase 3- internal tandem duplication; MYBL2, Myb-related protein B.

This study suggested that METTL3 facilitated colorectal cancer (CRC) cell invasion and migration through the circ1662-YAP1-SMAD3 axis, and further analysis confirmed METTL3-induced circ1662 promoted EMT, accelerating CRC metastasis via the YAP1-SMAD3 signaling pathway (170). In another study, METTL3 mediated the $\mathrm{m}^{6} \mathrm{~A}$ methylation of circCUX1 and stabilized its expression in hypopharyngeal squamous cell carcinoma (HPSCC), which lead to radioresistance of HPSCC through the caspase-1 pathway (140). Chen et al (139) also revealed that circNSUN2 was exported by another $\mathrm{m}^{6} \mathrm{~A}$ regulator, YTHDC1, from the nucleus to the cytoplasm in an $\mathrm{m}^{6} \mathrm{~A}$ methylation-dependent manner and this was essential for CRC cells' invasive ability.

At present, the mechanism of $\mathrm{m}^{6} \mathrm{~A}$ modification of circRNA in AML is unclear and related studies are yet to be reported. As a result, several hypotheses on how epigenetic modification of circRNAs may influence AML disease are proposed in this present study. It is speculated that the epigenetic modification of circRNAs might prevent miRNA-mRNA binding in AML by occupying the miRNA binding sites. Studies have indicated that circRNAs participate in AML pathogenesis by sponging miRNAs to inhibit their function and promote the expression of the miRNA target genes (Table II). In addition, it has been demonstrated that $\mathrm{m}^{6} \mathrm{~A}$ modification was found to promote
miRNA degradation as well as the translational inhibition of downstream target genes. However, $\mathrm{m}^{6} \mathrm{~A}$ modification was suggested to protect mRNA degradation mediated by miRNA (171). Taken together, $\mathrm{m}^{6} \mathrm{~A}$ modification of circRNA may facilitate circRNA sponging miRNA interaction, which is found in the pathogenesis of several diseases including AML. Second, during AML pathogenesis, epigenetically modified circRNAs may transmit information to the microenvironment via exosomes. Exosomes, which were first identified in 1983, are 50-nm vesicles that play an important role in intracellular and extracellular communication (172). Pre-mRNAs containing Dicer, $\mathrm{AGO} 2$ and trans-acting regulatory $\mathrm{RBP}$ were found in the exosomes of breast cancer cells according to a previous study (173). Furthermore, an AML study revealed that exosomes, emerging as key modulators of hematopoiesis, were found to suppress hematopoiesis in AML (174). That study found that exosomes released from leukemia blasts were able to suppress HPC function in two ways: i) Through stromal reprogramming of niche retention factors and ii) through AML exosome-directed miRNA delivery to HPCs. These could transform the bone marrow niche into a leukemia growth-permissive microenvironment. Third, certain circRNAs can be translated into proteins, and these proteins are suggested to be involved in RNA processing. As a result, 
it is speculated that epigenetic modifications of circRNAs, such as $\mathrm{m}^{6} \mathrm{~A}$, may play a key role in AML by influencing RNA splicing and processing. Furthermore, the fact that circRNAs are potential therapeutic targets, or diagnostic or prognostic markers in AML, means their epigenetic modification may affect RNA stability and promote AML pathogenesis.

\section{Conclusion}

In conclusion, the role of circRNAs in carcinogenesis, including AML, is currently a major focus of cancer research. Although alterations in circRNA epigenetic modifications may have an impact on hematopoiesis and AML development, further studies are required to confirm this hypothesis. Therefore, it may be necessary to identify alterations in circRNA epigenetic modifications in AML, as well as the regulatory mechanisms behind these modifications, which could further elucidate the specific roles of circRNAs in this disease. These studies may provide new insights into AML pathogenesis and therapy.

\section{Acknowledgements}

Not applicable.

\section{Funding}

This study was supported in part by Grants-in-Aid from the National Natural Science Foundation of China (grant nos. 81300428 and 81800167); Joints Funds for the Innovation of Science and Technology, Fujian Province (grant nos. 2018Y9010 and 2018Y9205); Qihang Foundation of Fujian Medical University (grant no. 2020QH2015); and the Construction project of Fujian Medical Center of Hematology, Clinical Research Center for Hematological Malignancies of Fujian Province (grant no. Min201704).

\section{Availability of data and materials}

Not applicable.

\section{Authors' contributions}

MAI, DW and JS contributed to study conceptualization. MAI was the primary contributor with support from FZ, WZ, HF and $\mathrm{HZ}$ in writing the original draft, and it was reviewed and edited by MAI, YL and RC. All the authors have read and approved the final manuscript. Data authentication is not applicable.

\section{Ethics approval and consent to participate}

Not applicable.

\section{Patient consent for publication}

Not applicable.

\section{Competing interests}

The authors declare that they have no competing interests.

\section{References}

1. Chen LL and Yang L: Regulation of circRNA biogenesis. RNA Biol 12: 381-388, 2015.

2. Bartel DP: MicroRNAs: Target recognition and regulatory functions. Cell 136: 215-233, 2009.

3. Dong Y, He D, Peng Z, Peng W, Shi W, Wang J, Li B, Zhang C and Duan C: Circular RNAs in cancer: An emerging key player. J Hematol Oncol 10: 2, 2017.

4. Memczak S, Jens M, Elefsinioti A, Torti F, Krueger J, Rybak A, Maier L, Mackowiak S, Gregersen LH, Munschauer M, et al: Circular RNAs are a large class of animal RNAs with regulatory potency. Nature 495: 333-338, 2013.

5. Zhang Y, Zhang XO, Chen T, Xiang JF, Yin QF, Xing YH, Zhu S, Yang L and Chen LL: Circular intronic long noncoding RNAs. Mol Cell 51: 792-806, 2013.

6. Dupont C, Armant DR and Brenner CA: Epigenetics: Definition, mechanisms and clinical perspective. Semin Reprod Med 27: 351-357, 2009.

7. Bolisetty MT and Graveley BR: Circuitous route to transcription regulation. Mol Cell 51: 705-706, 2013.

8. Suzuki $H$ and Tsukahara T: A view of pre-mRNA splicing from RNase R resistant RNAs. Int J Mol Sci 15: 9331-9342, 2014.

9. Jeck WR, Sorrentino JA, Wang K, Slevin MK, Burd CE, Liu J, Marzluff WF and Sharpless NE: Circular RNAs are abundant, conserved, and associated with ALU repeats. RNA 19: 141-157, 2013.

10. Gruner H, Cortés-López M, Cooper DA, Bauer M and Miura P: CircRNA accumulation in the aging mouse brain. Sci Rep 6: 38907, 2016.

11. Hansen TB, Jensen TI, Clausen BH, Bramsen JB, Finsen B, Damgaard CK and Kjems J: Natural RNA circles function as efficient microRNA sponges. Nature 495: 384-388, 2013.

12. Ashwal-Fluss R, Meyer M, Pamudurti NR, Ivanov A, Bartok O, Hanan M, Evantal N, Memczak S, Rajewsky N and Kadener S: CircRNA biogenesis competes with pre-mRNA splicing. Mol Cell 56: 55-66, 2014.

13. Li Z, Huang C, Bao C, Chen L, Lin M, Wang X, Zhong G, Yu B, Hu W, Dai L, et al: Exon-intron circular RNAs regulate transcription in the nucleus. Nat Struct Mol Biol 22: 256-264, 2015.

14. Meng S, Zhou H, Feng Z, Xu Z, Tang Y, Li P and Wu M: CircRNA: Functions and properties of a novel potential biomarker for cancer. Mol Cancer 16: 94, 2017.

15. Yang Y, Fan X, Mao M, Song X, Wu P, Zhang Y, Jin Y, Yang Y, Chen LL, Wang Y, et al: Extensive translation of circular RNAs driven by N6-methyladenosine. Cell Res 27: 626-641, 2017.

16. Zhou C, Molinie B, Daneshvar K, Pondick JV, Wang J, Van Wittenberghe N, Xing Y, Giallourakis CC and Mullen AC: Genome-wide maps of m6A circRNAs identify widespread and cell-type-specific methylation patterns that are distinct from mRNAs. Cell Rep 20: 2262-2276, 2017.

17. Gapp K, Woldemichael BT, Bohacek J and Mansuy IM: Epigenetic regulation in neurodevelopment and neurodegenerative diseases. Neuroscience 264: 99-111, 2014.

18. Trowbridge JJ, Snow JW, Kim J and Orkin SH: DNA methyltransferase 1 is essential for and uniquely regulates hematopoietic stem and progenitor cells. Cell Stem Cell 5: 442-449, 2009.

19. Harman MF and Martín MG: Epigenetic mechanisms related to cognitive decline during aging. J Neurosci Res 98: 234-246, 2020.

20. Feinberg AP and Tycko B: The history of cancer epigenetics. Nat Rev Cancer 4: 143-153, 2004.

21. Jones PA: Functions of DNA methylation: Islands, start sites, gene bodies and beyond. Nat Rev Genet 13: 484-492, 2012.

22. Hájková H, Marková J,Haškovec C, Šárová I, Fuchs O, Kostečka A, Cetkovský P, Michalová K and Schwarz J: Decreased DNA methylation in acute myeloid leukemia patients with DNMT3A mutations and prognostic implications of DNA methylation. Leuk Res 36: 1128-1133, 2012.

23. Bröske AM, Vockentanz L, Kharazi S, Huska MR, Mancini E, Scheller M, Kuhl C, Enns A, Prinz M, Jaenisch R, et al: DNA methylation protects hematopoietic stem cell multipotency from myeloerythroid restriction. Nat Genet 41: 1207-1215, 2009.

24. Bock C, Beerman I, Lien WH, Smith ZD, Gu H, Boyle P, Gnirke A, Fuchs E, Rossi DJ and Meissner A: DNA methylation dynamics during in vivo differentiation of blood and skin stem cells. Mol Cell 47: 633-647, 2012.

25. Hodges E, Molaro A, Dos Santos CO, Thekkat P, Song Q, Uren PJ, Park J, Butler J, Rafii S, McCombie WR, et al: Directional DNA methylation changes and complex intermediate states accompany lineage specificity in the adult hematopoietic compartment. Mol Cell 44: 17-28, 2011. 
26. Hogart A, Lichtenberg J, Ajay SS, Anderson S, NIH Intramural Sequencing Center; Margulies EH and Bodine DM: Genome-wide DNA methylation profiles in hematopoietic stem and progenitor cells reveal overrepresentation of ETS transcription factor binding sites. Genome Res 22: 1407-1418, 2012.

27. Tadokoro Y, Ema H, Okano M, Li E and Nakauchi H: De novo DNA methyltransferase is essential for self-renewal, but not for differentiation, in hematopoietic stem cells. J Exp Med 204: 715-722, 2007.

28. Jiang Y, Dunbar A, Gondek LP, Mohan S, Rataul M, O'Keefe C, Sekeres M, Saunthararajah Y and Maciejewski JP: Aberrant DNA methylation is a dominant mechanism in MDS progression to AML. Blood 113: 1315-1325, 2009.

29. Chen J, Odenike O and Rowley JD: Leukaemogenesis: More than mutant genes. Nat Rev Cancer 10: 23-36, 2010

30. Schoofs T, Berdel WE and Müller-Tidow C: Origins of aberrant DNA methylation in acute myeloid leukemia. Leukemia 28: 1-14, 2014.

31. Figueroa ME, Lugthart S, Li Y, Erpelinck-Verschueren C, Deng X, Christos PJ, Schifano E, Booth J, van Putten W, Skrabanek L, et al: DNA methylation signatures identify biologically distinct subtypes in acute myeloid leukemia. Cancer Cell 17: 13-27, 2010

32. Cole CB, Verdoni AM, Ketkar S,Leight ER, Russler-Germain DA, Lamprecht TL, Demeter RT, Magrini V and Ley TJ: PML-RARA requires DNA methyltransferase $3 \mathrm{~A}$ to initiate acute promyelocytic leukemia. J Clin Invest 126: 85-98, 2016.

33. Ley TJ, Miller C, Ding L, Raphael BJ, Mungall AJ, Robertson AG, Hoadley K, Triche TJ Jr, Laird PW, Batty JD, et al: Genomic and epigenomic landscapes of adult de novo acute myeloid leukemia. N Engl J Med 368: 2059-2074, 2013.

34. Thol F, Damm F, Lüdeking A, Winschel C, Wagner K, Morgan M, Yun H, Göhring G, Schlegelberger B, Hoelzer D, et al: Incidence and prognostic influence of DNMT3A mutations in acute myeloid leukemia. J Clin Oncol 29: 2889-2896, 2011.

35. Marková J, Michková P, Burčková K, Březinová J, Michalová K, Dohnalová A, Maaloufová JS, Soukup P, Vítek A, Cetkovský P and Schwarz J: Prognostic impact of DNMT3A mutations in patients with intermediate cytogenetic risk profile acute myeloid leukemia. Eur J Haematol 88: 128-135, 2012.

36. Alvarez S, Suela J, Valencia A, Fernández A, Wunderlich M Agirre X,Prósper F,Martín-Subero JI, Maiques A, Acquadro F, et al: DNA methylation profiles and their relationship with cytogenetic status in adult acute myeloid leukemia. PLoS One 5: e12197, 2010.

37. Akalin A, Garrett-Bakelman FE, Kormaksson M, Busuttil J, Zhang L, Khrebtukova I, Milne TA, Huang Y, Biswas D, Hess JL, et al: Base-pair resolution DNA methylation sequencing reveals profoundly divergent epigenetic landscapes in acute myeloid leukemia. PLoS Genet 8: e1002781, 2012.

38. Cimmino L, Dawlaty MM, Ndiaye-Lobry D, Yap YS Bakogianni S, Yu Y, Bhattacharyya S, Shaknovich R, Geng H, Lobry C, et al: Erratum: TET1 is a tumor suppressor of hematopoietic malignancy. Nat Immunol 16: 889, 2015.

39. Moran-Crusio K, Reavie L, Shih A, Abdel-Wahab O, Ndiaye-Lobry D, Lobry C, Figueroa ME, Vasanthakumar A, Patel J, Zhao X, et al: Tet2 loss leads to increased hematopoietic stem cell self-renewal and myeloid transformation. Cancer Cell 20: 11-24, 2011

40. Li Z, Cai X, Cai CL, Wang J, Zhang W, Petersen BE, Yang FC and Xu M: Deletion of Tet 2 in mice leads to dysregulated hematopoietic stem cells and subsequent development of myeloid malignancies. Blood 118: 4509-4518, 2011.

41. Abdel-Wahab O, Mullally A, Hedvat C, Garcia-Manero G, Patel J, Wadleigh M, Malinge S, Yao J, Kilpivaara O, Bhat R, et al Genetic characterization of TET1, TET2, and TET3 alterations in myeloid malignancies. Blood 114: 144-147, 2009.

42. Tefferi A, Lim KH, Abdel-Wahab O, Lasho TL, Patel J, Patnaik MM, Hanson CA, Pardanani A, Gilliland DG and Levine RL: Detection of mutant TET2 in myeloid malignancies other than myeloproliferative neoplasms: CMML, MDS, MDS/MPN and AML. Leukemia 23: 1343-1345, 2009.

43. Bacher U, Haferlach C, Schnittger S, Kohlmann A, Kern W and Haferlach T: Mutations of the TET 2 and CBL genes: Novel molecular markers in myeloid malignancies. Ann Hematol 89: 643-652, 2010.

44. Sato H, Wheat JC, Steidl U and Ito K: DNMT3A and TET2 in the pre-leukemic phase of hematopoietic disorders. Front Oncol 6 : $187,2016$.

45. Chan SM and Majeti R: Role of DNMT3A, TET2, and IDH1/2 mutations in pre-leukemic stem cells in acute myeloid leukemia. Int J Hematol 98: 648-657, 2013.
46. Weissmann S, Alpermann T, Grossmann V, Kowarsch A, Nadarajah N, Eder C, Dicker F, Fasan A, Haferlach C, Haferlach T, et al: Landscape of TET2 mutations in acute myeloid leukemia. Leukemia 26: 934-942, 2012.

47. Shih AH, Jiang Y, Meydan C, Shank K, Pandey S, Barreyro L, Antony-Debre I, Viale A, Socci N, Sun Y, et al: Mutational cooperativity linked to combinatorial epigenetic gain of function in acute myeloid leukemia. Cancer Cell 27: 502-515, 2015.

48. Rasmussen KD, Jia G, Johansen JV, Pedersen MT, Rapin N, Bagger F, Porse BT, Bernard OA, Christensen J, Helin K, et al: Loss of TET2 in hematopoietic cells leads to DNA hypermethylation of active enhancers and induction of leukemogenesis. Genes Dev 29: 910-922, 2015.

49. Berger SL: The complex language of chromatin regulation during transcription. Nature 447: 407-412, 2007.

50. Podobinska M, Szablowska-Gadomska I, Augustyniak J, Sandvig I, Sandvig A and Buzanska L: Epigenetic modulation of stem cells in neurodevelopment: The role of methylation and acetylation. Front Cell Neurosci 11: 23, 2017.

51. Zhang Y, Gilquin B, Khochbin S and Matthias P: Two catalytic domains are required for protein deacetylation. J Biol Chem 281: 2401-2404, 2006.

52. Uchida T, Kinoshita T, Nagai H, Nakahara Y, Saito H, Hotta T and Murate T: Hypermethylation of the p15INK4B gene in myelodysplastic syndromes. Blood 90: 1403-1409, 1997.

53. Melki JR, Vincent PC and Clark SJ: Concurrent DNA hypermethylation of multiple genes in acute myeloid leukemia. Cancer Res 59: 3730-3740, 1999.

54. Herman JG, Jen J, Merlo A and Baylin SB: Hypermethylationassociated inactivation indicates a tumor suppressor role for p15INK4B. Cancer Res 56: 722-727, 1996.

55. Jenuwein T: Translating the histone code. Science 293: 1074-1080, 2001.

56. van Dijk AD, Hu CW, de Bont ESJM, Qiu Y, Hoff FW, Yoo SY, Coombes KR, Qutub AA and Kornblau SM: Histone modification patterns using RPPA-based profiling predict outcome in acute myeloid leukemia patients. Proteomics 18: 1700379, 2018.

57. Zaghlool A, Halvardson J, Zhao JJ, Etemadikhah M, Kalushkova A, Konska K, Jernberg-Wiklund H, Thuresson AC and Feuk L: A role for the chromatin-remodeling factor BAZ1A in neurodevelopment. Hum Mutat 37: 964-975, 2016.

58. Olave IA, Reck-Peterson SL and Crabtree GR: Nuclear actin and actin-related proteins in chromatin remodeling. Annu Rev Biochem 71: 755-781, 2002

59. Choi KY, Yoo M and Han JH: Toward understanding the role of the neuron-specific BAF chromatin remodeling complex in memory formation. Exp Mol Med 47: e155, 2015.

60. Redner RL, Wang J and Liu JM: Chromatin remodeling and leukemia: New therapeutic paradigms. Blood 94: 417-428, 1999.

61. Sperlazza J, Rahmani M, Beckta J, Aust M, Hawkins E, Wang SZ, Zu Zhu S, Podder S, Dumur C, Archer K, et al: Depletion of the chromatin remodeler CHD4 sensitizes AML blasts to genotoxic agents and reduces tumor formation. Blood 126: 1462-1472, 2015

62. Denslow SA and Wade PA: The human Mi-2/NuRD complex and gene regulation. Oncogene 26: 5433-5438, 2007.

63. D'Alesio C, Punzi S, Cicalese A, Fornasari L, Furia L, Riva L, Carugo A, Curigliano G, Criscitiello C, Pruneri G, et al: RNAi screens identify CHD4 as an essential gene in breast cancer growth. Oncotarget 7: 80901-80915, 2016.

64. O'Shaughnessy A and Hendrich B: CHD4 in the DNA-damage response and cell cycle progression: Not so NuRDy now. Biochem Soc Trans 41: 777-782, 2013.

65. Polo SE, Kaidi A, Baskcomb L, Galanty Y and Jackson SP Regulation of DNA-damage responses and cell-cycle progression by the chromatin remodelling factor CHD4. EMBO J 29 : 3130-3139, 2010

66. Xia L, Huang W, Bellani M, Seidman MM, Wu K, Fan D, Nie Y, Cai Y, Zhang YW, Yu LR, et al: CHD4 has oncogenic functions in initiating and maintaining epigenetic suppression of multiple tumor suppressor genes. Cancer Cell 31: 653-668.e7, 2017.

67. Heshmati Y, Türköz G, Harisankar A, Kharazi S, Boström J, Dolatabadi EK, Krstic A, Chang D, Månsson R, Altun M, et al: The chromatin-remodeling factor CHD4 is required for maintenance of childhood acute myeloid leukemia. Haematologica 103 $1169-1181,2018$

68. Zhen T, Kwon EM, Zhao L, Hsu J, Hyde RK, Lu Y, Alemu L, Speck NA and Liu PP: Chd7 deficiency delays leukemogenesis in mice induced by Cbfb-MYH11. Blood 130: 2431-2442, 2017. 
69. Fazi F, Racanicchi S, Zardo G, Starnes LM, Mancini M Travaglini L, Diverio D, Ammatuna E, Cimino G, Lo-Coco F, et al: Epigenetic silencing of the myelopoiesis regulator microRNA-223 by the AML1/ETO oncoprotein. Cancer Cell 12: 457-466, 2007.

70. Li Y, Gao L, Luo X, Wang L, Gao X, Wang W, Sun J, Dou L, Li J, $\mathrm{Xu}$ C, et al: Epigenetic silencing of microRNA-193a contributes to leukemogenesis in $\mathrm{t}(8 ; 21)$ acute myeloid leukemia by activating the PTEN/PI3K signal pathway. Blood 121: 499-509, 2013.

71. Berger SL, Kouzarides T, Shiekhattar R and Shilatifard A: An operational definition of epigenetics. Genes Dev 23: 781-783, 2009.

72. Sun WJ, Li JH, Liu S, Wu J, Zhou H, Qu LH and Yang JH: RMBase: A resource for decoding the landscape of RNA modifications from high-throughput sequencing data. Nucleic Acids Res 44: D259-D265, 2016.

73. Lee M, Kim B and Kim VN: Emerging roles of RNA modification: m6A and U-tail. Cell 158: 980-987, 2014.

74. Flamand MN and Meyer KD: The epitranscriptome and synaptic plasticity. Curr Opin Neurobiol 59: 41-48, 2019.

75. Maden BE: The numerous modified nucleotides in eukaryotic ribosomal RNA. Prog Nucleic Acid Res Mol Biol 39: 241-303, 1990.

76. Wang X, Lu Z, Gomez A, Hon GC, Yue Y, Han D, Fu Y, Parisien M, Dai Q, Jia G, et al: N6-methyladenosine-dependent regulation of messenger RNA stability. Nature 505: 117-120, 2014.

77. Zhang $X$ and Jia GF: RNA epigenetic modification: N6methyladenosine. Yi Chuan 38: 275-288, 2016.

78. Wei CM, Gershowitz A and Moss B: Methylated nucleotides block 5 ' terminus of HeLa cell messenger RNA. Cell 4: 379-386, 1975.

79. Niu Y, Zhao X, Wu YS, Li MM, Wang XJ and Yang YG: N6-methyl-adenosine (m6A) in RNA: An old modification with a novel epigenetic function. Genomics Proteomics Bioinformatics 11: 8-17, 2013.

80. Meyer KD, Saletore Y, Zumbo P, Elemento O, Mason CE and Jaffrey SR: Comprehensive analysis of mRNA methylation reveals enrichment in 3' UTRs and near stop codons. Cell 149: 1635-1646, 2012

81. Dominissini D, Moshitch-Moshkovitz S, Schwartz S, Salmon-Divon M, Ungar L, Osenberg S, Cesarkas K, Jacob-Hirsch J, Amariglio N, Kupiec M, et al: Topology of the human and mouse m6A RNA methylomes revealed by m6A-seq. Nature 485: 201-206, 2012.

82. Chen K, Lu Z, Wang X, Fu Y,Luo GZ,Liu N,Han D, Dominissini D, Dai Q, Pan T and He C: High-resolution N(6)-methyladenosine (m(6) A) map using photo-crosslinking-assisted $\mathrm{m}(6) \mathrm{A}$ sequencing. Angew Chemie Int Ed 54: 1587-1590, 2015.

83. Linder B, Grozhik AV, Olarerin-George AO, Meydan C, Mason CE and Jaffrey SR: Single-nucleotide-resolution mapping of m6A and m6Am throughout the transcriptome. Nat Methods 12: 767-772, 2015

84. Roundtree IA and He C: RNA epigenetics-chemical messages for posttranscriptional gene regulation. Curr Opin Chem Biol 30: 46-51, 2016.

85. Ping XL, Sun BF, Wang L, Xiao W, Yang X, Wang WJ, Adhikari S, Shi Y, Lv Y, Chen YS, et al: Mammalian WTAP is a regulatory subunit of the RNA N6-methyladenosine methyltransferase. Cell Res 24: 177-189, 2014.

86. Liu J, Yue Y, Han D, Wang X, Fu Y, Zhang L, Jia G, Yu M, Lu Z, Deng X, et al: A METTL3-METTL14 complex mediates mammalian nuclear RNA N6-adenosine methylation. Nat Chem Biol 10: 93-95, 2014.

87. Bokar JA, Rath-Shambaugh ME, Ludwiczak R, Narayan P and Rottman F: Characterization and partial purification of mRNA N6-adenosine methyltransferase from HeLa cell nuclei. Internal mRNA methylation requires a multisubunit complex. J Biol Chem 269: 17697-17704, 1994

88. Schwartz S, Mumbach MR, Jovanovic M, Wang T, Maciag K, Bushkin GG, Mertins P, Ter-Ovanesyan D, Habib N, Cacchiarelli D, et al: Perturbation of $\mathrm{m} 6 \mathrm{~A}$ writers reveals two distinct classes of mrna methylation at internal and 5' sites. Cell Rep 8: 284-296, 2014.

89. Ke S, Alemu EA, Mertens C, Gantman EC, Fak JJ, Mele A, Haripal B, Zucker-Scharff I, Moore MJ, Park CY, et al: A majority of $\mathrm{m} 6 \mathrm{~A}$ residues are in the last exons, allowing the potential for 3' UTR regulation. Genes Dev 29: 2037-2053, 2015

90. Meyer KD, Patil DP, Zhou J, Zinoviev A, Skabkin MA, Elemento O, Pestova TV, Qian SB and Jaffrey SR: 5' UTR m6A promotes cap-independent translation. Cell 163: 999-1010, 2015.
91. Zhou J, Wan J, Gao X, Zhang X, Jaffrey SR and Qian SB Dynamic m6A mRNA methylation directs translational control of heat shock response. Nature 526: 591-594, 2015.

92. Pendleton KE, Chen B, Liu K, Hunter OV, Xie Y, Tu BP and Conrad NK: The U6 snRNA m 6 A methyltransferase METTL16 regulates SAM synthetase intron retention. Cell 169: 824-835. e14, 2017

93. Dina C, Meyre D, Gallina S, Durand E, Körner A, Jacobson P, Carlsson LMS, Kiess W, Vatin V, Lecoeur C, et al: Variation in FTO contributes to childhood obesity and severe adult obesity. Nat Genet 39: 724-726, 2007.

94. Jia G, Fu Y, Zhao X, Dai Q, Zheng G, Yang Y, Yi C, Lindahl T, Pan T, Yang YG and He C: N6-Methyladenosine in nuclear RNA is a major substrate of the obesity-associated FTO. Nat Chem Biol 7: 885-887, 2011

95.Zheng G, Dahl JA, Niu Y, Fedorcsak P, Huang CM, Li CJ, Vågbø CB, Shi Y, Wang WL, Song SH, et al: ALKBH5 is a mammalian RNA demethylase that impacts RNA metabolism and mouse fertility. Mol Cell 49: 18-29, 2013.

96. Fu Y, Jia G, Pang X, Wang RN, Wang X, Li CJ, Smemo S, Dai Q, Bailey KA, Nobrega MA, et al: FTO-mediated formation of N6-hydroxymethyladenosine and N6-formyladenosine in mammalian RNA. Nat Commun 4: 1798, 2013.

97. Zhao X, Yang Y, Sun BF, Shi Y, Yang X, Xiao W, Hao YJ, Ping XL, Chen YS, Wang WJ, et al: FTO-dependent demethylation of N6-methyladenosine regulates mRNA splicing and is required for adipogenesis. Cell Res 24: 1403-1419, 2014.

98. Hess ME, Hess S, Meyer KD, Verhagen LAW, Koch L, Brönneke HS, Dietrich MO, Jordan SD, Saletore Y, Elemento O, et al: The fat mass and obesity associated gene (Fto) regulates activity of the dopaminergic midbrain circuitry. Nat Neurosci 16: 1042-1048, 2013

99. Geula S, Moshitch-Moshkovitz S, Dominissini D, Mansour AA, Kol N, Salmon-Divon M, Hershkovitz V, Peer E, Mor N, Manor YS, et al: Stem cells. m6A mRNA methylation facilitates resolution of naïve pluripotency toward differentiation. Science 347: 1002-1006, 2015.

100. Li Z, Weng H, Su R, Weng X, Zuo Z, Li C, Huang H, Nachtergaele S, Dong L, Hu C, et al: FTO plays an oncogenic role in acute myeloid leukemia as a N 6-methyladenosine RNA demethylase. Cancer Cell 31: 127-141, 2017.

101. Jaffrey SR and Kharas MG: Emerging links between m6A and misregulated mRNA methylation in cancer. Genome Med 9: 2, 2017.

102.Zhang Z, Theler D, Kaminska KH, Hiller M, de la Grange P, Pudimat R, Rafalska I, Heinrich B, Bujnicki JM, Allain FHT and Stamm S: The YTH domain is a novel RNA binding domain. J Biol Chem 285: 14701-14710, 2010.

103. Xu C, Wang X, Liu K, Roundtree IA, Tempel W, Li Y, Lu Z, $\mathrm{He} \mathrm{C}$ and Min J: Structural basis for selective binding of m6A RNA by the YTHDC1 YTH domain. Nat Chem Biol 10: 927-929, 2014

104. Luo S and Tong L: Molecular basis for the recognition of methylated adenines in RNA by the eukaryotic YTH domain. Proc Natl Acad Sci USA 111: 13834-13839, 2014.

105. Zhu T, Roundtree IA, Wang P, Wang X, Wang L, Sun C, Tian Y, Li J, He C and Xu Y: Crystal structure of the YTH domain of YTHDF2 reveals mechanism for recognition of N6-methyladenosine. Cell Res 24: 1493-1496, 2014.

106. Wang X, Zhao BS, Roundtree IA, Lu Z, Han D, Ma H, Weng X, Chen K, Shi $\mathrm{H}$ and $\mathrm{He} \mathrm{C}$ : N6-methyladenosine modulates messenger RNA translation efficiency. Cell 161: 1388-1399, 2015.

107. Wang Y, Li Y, Toth JI, Petroski MD, Zhang Z and Zhao JC: N6-methyladenosine modification destabilizes developmental regulators in embryonic stem cells. Nat Cell Biol 16: 191-198, 2014.

108. Fustin JM, Doi M, Yamaguchi Y, Hida H, Nishimura S, Yoshida M, Isagawa T, Morioka MS, Kakeya H, Manabe I and Okamura H: RNA-methylation-dependent rna processing controls the speed of the circadian clock. Cell 155: 793-806, 2013.

109. Alarcón CR, Lee H, Goodarzi H, Halberg N and Tavazoie SF N6-methyladenosine marks primary microRNAs for processing. Nature 519: 482-485, 2015

110. Chen T, Hao YJ, Zhang Y, Li MM, Wang M, Han W, Wu Y, Lv Y, Hao J, Wang L, et al: m6A RNA methylation is regulated by MicroRNAs and promotes reprogramming to pluripotency. Cell Stem Cell 16: 289-301, 2015

111. Liu N, Dai Q, Zheng G, He C, Parisien M and Pan T: N6-methyladenosine-dependent RNA structural switches regulate RNA-protein interactions. Nature 518: 560-564, 2015. 
112. Klungland A and Dahl JA: Dynamic RNA modifications in disease. Curr Opin Genet Dev 26: 47-52, 2014.

113. Kwok CT, Marshall AD, Rasko JEJ and Wong JJL: Erratum to: Genetic alterations of m6A regulators predict poorer survival in acute myeloid leukemia. J Hematol Oncol 10: 49, 2017.

114. Su R, Dong L, Li C, Nachtergaele S, Wunderlich M, Qing Y, Deng X, Wang Y, Weng X, Hu C, et al: R-2HG exhibits anti-tumor activity by targeting FTO/m6A/MYC/CEBPA signaling. Cell 172: 90-105.e23, 2018

115. Vu LP, Pickering BF, Cheng Y, Zaccara S, Nguyen D, Minuesa G, Chou T, Chow A, Saletore Y, MacKay M, et al: The N6-methyladenosine (m6A)-forming enzyme METTL3 controls myeloid differentiation of normal hematopoietic and leukemia cells. Nat Med 23: 1369-1376, 2017

116. Weng H, Huang H, Wu H, Qin X, Zhao BS, Dong L, Shi H, Skibbe J, Shen C, Hu C, et al: METTL14 inhibits hematopoietic stem/progenitor differentiation and promotes leukemogenesis via mRNA m6A modification. Cell Stem Cell 22: 191-205.e9, 2018.

117. Chhabra R: miRNA and methylation: A multifaceted liaison. Chembiochem 16: 195-203, 2015.

118. Hall RH: Isolation of 3-methyluridine and 3-methylcytidine from soluble ribonucleic acid. Biochem Biophys Res Commun 12: 361-364, 1963

119. Xu L, Liu X, Sheng N, Oo KS, Liang J, Chionh YH, Xu J, Ye F, Gao YG, Dedon PC and Fu XY: Three distinct 3-methylcytidine (m3C) methyltransferases modify tRNA and mRNA in mice and humans. J Biol Chem 292: 14695-14703, 2017.

120. Glasner H, Riml C, Micura R and Breuker K: Label-free, direct localization and relative quantitation of the RNA nucleobase methylations $\mathrm{m} 6 \mathrm{~A}, \mathrm{~m} 5 \mathrm{C}, \mathrm{m} 3 \mathrm{U}$, and $\mathrm{m} 5 \mathrm{U}$ by top-down mass spectrometry. Nucleic Acids Res 45: 8014-8025, 2017.

121. Li X, Zhu P, Ma S, Song J, Bai J, Sun F and Yi C: Chemical pulldown reveals dynamic pseudouridylation of the mammalian transcriptome. Nat Chem Biol 11: 592-597, 2015.

122. Charette $M$ and Gray MW: Pseudouridine in RNA: What, where, how, and why. IUBMB Life 49: 341-351, 2000.

123. Ofengand J: Ribosomal RNA pseudouridines and pseudouridine synthases. FEBS Lett 514: 17-25, 2002.

124. Jack K, Bellodi C, Landry DM, Niederer RO, Meskauskas A, Musalgaonkar S, Kopmar N, Krasnykh O, Dean AM, Thompson SR, et al: rRNA pseudouridylation defects affect ribosomal ligand binding and translational fidelity from yeast to human cells. Mol Cell 44: 660-666, 2011.

125. Kiss T, Fayet-Lebaron E and Jády BE: Box H/ACA small ribonucleoproteins. Mol Cell 37: 597-606, 2010

126. Yu AT, Ge J and Yu YT: Pseudouridines in spliceosomal snRNAs. Protein Cell 2: 712-725, 2011.

127. Karijolich $\mathrm{J}$ and Yu YT: Converting nonsense codons into sense codons by targeted pseudouridylation. Nature 474: 395-398, 2011.

128. Rosselló-Tortella M, Ferrer G and Esteller M: Epitranscriptomics in hematopoiesis and hematologic malignancies. Blood Cancer Discov 1: 26-31, 2020.

129. Alseth I, Dalhus B and Bjørås M: Inosine in DNA and RNA. Curr Opin Genet Dev 26: 116-123, 2014.

130. Bass BL, Nishikura K, Keller W, Seeburg PH, Emeson RB, O'Connell MA, Samuel CE and Herbert A: A standardized nomenclature for adenosine deaminases that act on RNA. RNA 3: 947-949, 1997.

131. Li X, Yang L and Chen LL: The biogenesis, functions, and challenges of circular RNAs. Mol Cell 71: 428-442, 2018.

132. Legnini I, Di Timoteo G, Rossi F, Morlando M, Briganti F, Sthandier O, Fatica A, Santini T, Andronache A, Wade M, et al: Circ-ZNF609 is a circular rna that can be translated and functions in myogenesis. Mol Cell 66: 22-37.e9, 2017.

133. Pamudurti NR, Bartok O, Jens M, Ashwal-Fluss R, Stottmeister C, Ruhe L, Hanan M, Wyler E, Perez-Hernandez D, Ramberger E, et al: Translation of CircRNAs. Mol Cell 66: 9-21. e7, 2017.

134. Haimov O, Sinvani H and Dikstein R: Cap-dependent, scanning-free translation initiation mechanisms. Biochim Biophys Acta 1849: 1313-1318, 2015.

135. Yang Y, Gao X, Zhang M, Yan S, Sun C, Xiao F, Huang N, Yang X, Zhao K, Zhou H, et al: Novel role of FBXW7 Circular RNA in repressing glioma tumorigenesis. J Natl Cancer Inst 110: 304-315, 2018.

136. Zhang M, Huang N, Yang X, Luo J, Yan S, Xiao F, Chen W, Gao X, Zhao K, Zhou H, et al: A novel protein encoded by the circular form of the SHPRH gene suppresses glioma tumorigenesis. Oncogene 37: 1805-1814, 2018.
137. Liang WC, Wong CW, Liang PP, Shi M, Cao Y, Rao ST, Tsui SKW, Waye MMY, Zhang Q, Fu WM and Zhang JF: Translation of the circular RNA $\operatorname{circ} \beta$-catenin promotes liver cancer cell growth through activation of the wnt pathway. Genome Biol 20: 84, 2019.

138. Huang X, He M, Huang S, Lin R, Zhan M, Yang D, Shen H, $\mathrm{Xu}$ S, Cheng W, Yu J, et al: Circular RNA circERBB2 promotes gallbladder cancer progression by regulating PA2G4-dependent rDNA transcription. Mol Cancer 18: 166, 2019.

139. Chen RX, Chen X, Xia LP, Zhang JX, Pan ZZ, Ma XD, Han K, Chen JW, Judde JG, Deas O, et al: N 6-methyladenosine modification of circNSUN2 facilitates cytoplasmic export and stabilizes HMGA2 to promote colorectal liver metastasis. Nat Commun 10: 4695, 2019.

140. Wu P, Fang X, Liu Y, Tang Y, Wang W, Li X and Fan Y: N6-methyladenosine modification of circCUX1 confers radioresistance of hypopharyngeal squamous cell carcinoma through caspase1 pathway. Cell Death Dis 12: 298, 2021.

141. Park OH, Ha H, Lee Y, Boo SH, Kwon DH, Song HK and Kim YK: Endoribonucleolytic cleavage of m6A-containing RNAs by RNase P/MRP complex. Mol Cell 74: 494-507.e8, 2019.

142. Zhang L, Hou C, Chen C, Guo Y, Yuan W, Yin D, Liu J and Sun Z: The role of N6-methyladenosine (m6A) modification in the regulation of circRNAs. Mol Cancer 19: 105, 2020.

143. Chen YG, Chen R, Ahmad S, Verma R, Kasturi SP, Amaya L, Broughton JP, Kim J, Cadena C, Pulendran B, et al: N6-methyladenosine modification controls circular RNA immunity. Mol Cell 76: 96-109.e9, 2019.

144. Lux S, Blätte TJ, Gillissen B, Richter A, Cocciardi S, Skambraks S, Schwarz K, Schrezenmeier H, Döhner H, Döhner K, et al: Deregulated expression of circular RNAs in acute myeloid leukemia. Blood Adv 5: 1490-1503, 2021.

145. Bell CC, Fennell KA, Chan YC, Rambow F, Yeung MM, Vassiliadis D, Lara L, Yeh P, Martelotto LG, Rogiers A, et al: Targeting enhancer switching overcomes non-genetic drug resistance in acute myeloid leukaemia. Nat Commun 10: 2723, 2019.

146. Arteaga CL and Engelman JA: ERBB receptors: From oncogene discovery to basic science to mechanism-based cancer therapeutics. Cancer Cell 25: 282-303, 2014.

147. Conn SJ, Pillman KA, Toubia J, Conn VM, Salmanidis M, Phillips CA, Roslan S, Schreiber AW, Gregory PA and Goodall GJ: The RNA binding protein quaking regulates formation of circRNAs. Cell 160: 1125-1134, 2015.

148. L'Abbate A, Tolomeo D, Cifola I, Severgnini M, Turchiano A, Augello B, Squeo G, D'Addabbo P, Traversa D, Daniele G, et al: MYC-containing amplicons in acute myeloid leukemia: Genomic structures, evolution, and transcriptional consequences. Leukemia 32: 2152-2166, 2018.

149. Guarnerio J, Bezzi M, Jeong JC, Paffenholz SV, Berry K, Naldini MM, Lo-Coco F, Tay Y, Beck AH and Pandolfi PP: Oncogenic role of fusion-circRNAs derived from cancer-associated chromosomal translocations. Cell 165: 289-302, 2016.

150. Wu DM, Wen X, Han XR, Wang S, Wang YJ, Shen M, Fan SH, Zhang ZF, Shan Q, Li MQ, et al: Role of circular RNA DLEU2 in human acute myeloid leukemia. Mol Cell Biol 38: e00259-e00218, 2018.

151. Ping L, Jian-Jun C, Chu-Shu L, Guang-Hua L and Ming Z: Silencing of circ_0009910 inhibits acute myeloid leukemia cell growth through increasing miR-20a-5p. Blood Cells Mol Dis 75: 41-47, 2019.

152. Fan H, Li Y, Liu C, Liu Y, Bai J and Li W: Circular RNA-100290 promotes cell proliferation and inhibits apoptosis in acute myeloid leukemia cells via sponging miR-203. Biochem Biophys Res Commun 507: 178-184, 2018.

153. Chen H, Liu T, Liu J, Feng Y, Wang B, Wang J, Bai J, Zhao W, Shen Y, Wang X, et al: Circ-ANAPC7 is upregulated in acute myeloid leukemia and appears to target the miR-181 family. Cell Physiol Biochem 47: 1998-2007, 2018.

154. Li W, Zhong C, Jiao J, Li P, Cui B, Ji C and Ma D: Characterization of hsa_circ_0004277 as a new biomarker for acute myeloid leukemia via circular RNA profile and bioinformatics analysis. Int J Mol Sci 18: 597, 2017.

155. Shang J, Chen WM, Wang ZH, Wei TN, Chen ZZ and Wu WB: CircPAN3 mediates drug resistance in acute myeloid leukemia through the miR-153-5p/miR-183-5p-XIAP axis. Exp Hematol 70: 42-54.e3, 2019.

156. Hirsch S, Blätte TJ, Grasedieck S, Cocciardi S, Rouhi A, Jongen-Lavrencic M, Paschka P, Krönke J, Gaidzik VI, Döhner H, et al: Circular RNAs of the nucleophosmin (NPM1) gene in acute myeloid leukemia. Haematologica 102: 2039-2047, 2017. 
157. Chen LL: The biogenesis and emerging roles of circular RNAs. Nat Rev Mol Cell Biol 17: 205-211, 2016.

158. Okcanoğlu TB and Gündüz C: Circular RNAs in leukemia (Review). Biomed Rep 10: 87-91, 2019.

159. Qu S, Yang X, Li X, Wang J, Gao Y, Shang R, Sun W, Dou K and Li H: Circular RNA: A new star of noncoding RNAs. Cancer Lett 365: 141-148, 2015.

160. Dudekula DB, Panda AC, Grammatikakis I, De S, Abdelmohsen K and Gorospe M: CircInteractome: A web tool for exploring circular RNAs and their interacting proteins and microRNAs. RNA Biol 13: 34-42, 2016.

161. Wang E, Lu SX, Pastore A, Chen X, Imig J, Lee SC, Hockemeyer K, Ghebrechristos YE, Yoshimi A, Inoue D, et al: Targeting an RNA-binding protein network in acute myeloid leukemia. Cancer Cell 35: 369-384.e7, 2019.

162. Yoshida K, Sanada M, Shiraishi Y, Nowak D, Nagata Y, Yamamoto R, Sato Y, Sato-Otsubo A, Kon A, Nagasaki M, et al: Frequent pathway mutations of splicing machinery in myelodysplasia. Nature 478: 64-69, 2011.

163. Sun YM, Wang WT, Zeng ZC, Chen TQ, Han C, Pan Q, Huang W, Fang K, Sun LY, Zhou YF, et al: circMYBL2, a circRNA from MYBL2, regulates FLT3 translation by recruiting PTBP1 to promote FLT3-ITD AML progression. Blood 134: 1533-1546, 2019.

164. Guil S and Esteller M: Cis-acting noncoding RNAs: Friends and foes. Nat Struct Mol Biol 19: 1068-1075, 2012.

165. Mercer TR and Mattick JS: Structure and function of long noncoding RNAs in epigenetic regulation. Nat Struct Mol Biol 20: 300-307, 2013

166. Conn VM, Hugouvieux V, Nayak A, Conos SA, Capovilla G Cildir G, Jourdain A, Tergaonkar V, Schmid M, Zubieta C and Conn SJ: A circRNA from SEPALLATA3 regulates splicing of its cognate mRNA through R-loop formation. Nat Plants 3 : 17053,2017
167. Schmitz KM, Mayer C, Postepska A and Grummt I: Interaction of noncoding RNA with the rDNA promoter mediates recruitment of DNMT3b and silencing of rRNA genes. Genes Dev 24: 2264-2269, 2010

168. Starke S, Jost I, Rossbach O, Schneider T, Schreiner S, Hung LH and Bindereif A: Exon circularization requires canonical splice signals. Cell Rep 10: 103-111, 2015.

169. van Rossum D, Verheijen BM and Pasterkamp RJ: Circular RNAs: Novel regulators of neuronal development. Front Mol Neurosci 9: 74, 2016

170. Chen C, Yuan W, Zhou Q, Shao B, Guo Y, Wang W, Yang S, Guo Y, Zhao L, Dang Q, et al: N6-methyladenosine-induced circ1662 promotes metastasis of colorectal cancer by accelerating YAP1 nuclear localization. Theranostics 11: 4298-4315, 2021.

171. Dai F, Wu Y, Lu Y, An C, Zheng X, Dai L, Guo Y, Zhang L, $\mathrm{Li} \mathrm{H}, \mathrm{Xu} \mathrm{W}$ and Gao W: Crosstalk between RNA m6A modification and non-coding RNA contributes to cancer growth and progression. Mol Ther Nucleic Acids 22: 62-71, 2020.

172. Harding CV, Heuser JE and Stahl PD: Exosomes: Looking back three decades and into the future. J Cell Biol 200: 367-371, 2013.

173. Melo SA, Sugimoto H, O'Connell JT, Kato N, Villanueva A, Vidal A, Qiu L, Vitkin E, Perelman LT, Melo CA, et al: Cancer exosomes perform cell-independent MicroRNA biogenesis and promote tumorigenesis. Cancer Cell 26: 707-721, 2014.

174. Boyiadzis M and Whiteside TL: Exosomes in acute myeloid leukemia inhibit hematopoiesis. Curr Opin Hematol 25: 279-284, 2018

This work is licensed under a Creative Commons Attribution-NonCommercial-NoDerivatives 4.0 International (CC BY-NC-ND 4.0) License. 